FedUni ResearchOnline

http://researchonline.federation.edu.au

This is the peer-reviewed version of the following article:

Cant, R., Cooper, S. (2017) The value of simulation-based learning in prelicensure nurse education: A state-of-the-art review and meta-analysis. Nurse Education in Practice, 70, 45-62.

Which has been published in final form at:

https://doi.org/10.1016/j.nepr.2017.08.012

Copyright (C) 2017 Elsevier B.V. All rights reserved. 


\section{Accepted Manuscript}

The value of simulation-based learning in pre-licensure nurse education: A state-ofthe-art review and meta-analysis

Robyn P. Cant, Simon J. Cooper

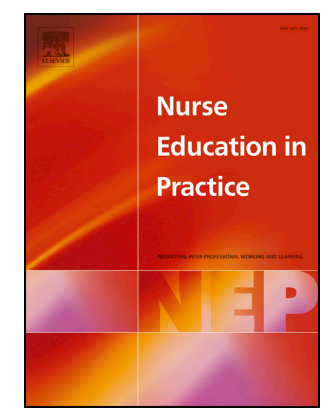

PII:

S1471-5953(16)30161-5

DOI:

10.1016/j.nepr.2017.08.012

Reference: $\quad$ YNEPR 2263

To appear in: Nurse Education in Practice

Received Date: 4 November 2016

Revised Date: 11 May 2017

Accepted Date: 11 August 2017

Please cite this article as: Cant, R.P., Cooper, S.J., The value of simulation-based learning in prelicensure nurse education: A state-of-the-art review and meta-analysis, Nurse Education in Practice (2017), doi: 10.1016/j.nepr.2017.08.012.

This is a PDF file of an unedited manuscript that has been accepted for publication. As a service to our customers we are providing this early version of the manuscript. The manuscript will undergo copyediting, typesetting, and review of the resulting proof before it is published in its final form. Please note that during the production process errors may be discovered which could affect the content, and all legal disclaimers that apply to the journal pertain. 


\title{
THE VALUE OF SIMULATION-BASED LEARNING IN PRE- LICENSURE NURSE EDUCATION: A STATE-OF-THE-ART REVIEW AND META-ANALYSIS
}

\author{
Authors \\ Robyn P. Cant ${ }^{1,2}$, Simon J Cooper ${ }^{2}$
}

1. Nursing and Midwifery, Monash University,

Melbourne, Victoria, 3806, Australia

2. School of Nursing Midwifery and Healthcare, Federation University Australia, Churchill, Victoria, 3842 Australia

Corresponding author:

Dr Robyn Cant

Nursing and Midwifery,

Monash University,

Melbourne, Victoria, 3806, Australia

E: robyn.cant@monash.edu

Ph: +61438363634

Acknowledgements

We acknowledge the assistance of Jo-Ann Larkins during early stages of study selection.

Conflict of interest statement

The authors declare they have no conflict of interest.

Funding statement

No funding was provided for this study 


\section{ABSTRACT}

Simulation modalities are numerous in nursing education, with a need to reveal their range and impact. We reviewed current evidence for effectiveness of medium to high fidelity simulation as an education mode in pre-licensure/pre-registration nurse education. A state-ofthe-art review and meta-analyses was conducted based on a systematic search of publications in English between 2010-2015. Of 72 included studies, 43 were quantitative primary studies (mainly quasi-experimental designs), 13 were qualitative studies and 16 were reviews of literature. Forty of 43 primary studies reported benefits to student learning, and student satisfaction was high. Simulation programs provided multi-modal ways of learning. A metaanalysis ( 8 studies, $n=652$ participants) identified that simulation programs significantly improved clinical knowledge from baseline. The weighted mean increase was 5.0 points (CI: 3.25-6.82) on a knowledge measure. Other objectively rated measures (eg, trained observers with checklists) were few. Reported subjective measures such as confidence and satisfaction when used alone have a strong potential for results bias. Studies presented valid empirical evidence, but larger studies are required. Simulation programs in pre-licensure nursing curricula demonstrate innovation and excellence. The programs should be shared across the discipline to facilitate development of multimodal learning for both pre-licensure and postgraduate nurses.

\section{KEYWORDS:}

e-simulation; experiential learning; literature review; nursing, students; simulation; virtual clinical simulation 


\section{HIGHLIGHTS}

- Simulation education statistically improves nursing students' knowledge

- Studies report improvements to students' confidence, competence and self-efficacy

- Programs demonstrate innovation and excellence, teaching a wide-range of topics

- Programs should be shared across the discipline to facilitate development of multimodal learning 
Manuscript

\section{INTRODUCTION}

Simulation-based learning is fundamental in learning to be a nurse and is increasingly incorporated in nursing curricula. This method of education incorporates goal-based role play, enabling students to practice of a range of skills without risk to real patients (Motola and Devine 2013). Based on nursing students' feedback about confidence levels and satisfaction, students are known to enjoy simulation as a teaching and learning technique (Bogossian et al., 2013, Yuan et al., 2014, Levett-Jones et al., 2011, McCaughey and Traynor 2010). Learning outcomes have predominantly been evaluated using self-reported measures and subjective assessments, thus leaving questions about the effectiveness of simulationbased learning.

The focus on simulation education modalities in nursing education over the last decade has policy and practical antecedents. This includes recognition that simulation-based scenarios can help students to learn and can prepare them for clinical practice (Lapkin et al., 2010). Simulation offers repeated practice opportunities especially for the management of less common conditions (Motola and Devine 2013), reducing the time it takes to reach competency. Simulation based education is also considered to be a valid substitution for some clinical training hours in pre-registration nursing courses in the USA and the UK (Larue et al., 2015, Ricketts et al., 2013). Further, the international shortage of clinical placement venues has driven the rise in simulation-based education programs (Ricketts et al., 2013).

Research into simulation-based education in nursing has escalated in the last five years and reports have increased exponentially. The SCOPUS database records from the last 20 years indicate that around 40 nursing simulation studies were published annually. However, this increased eight-fold between 2011 and 2015, to an average of 324 per year. Hence, it is timely to re-examine the recent progression of simulation research and to explore its efficacy. 
As there is no single objective measure of learning, simulation studies have based their evaluation on various criteria such as knowledge improvement, skills development, confidence levels, critical thinking, and psychomotor skills (Cant and Cooper 2010). In a systematic review of manikin-based high fidelity nursing simulation Lapkin et al., (2010) reported positive educational effects for knowledge acquisition and for clinical reasoning. A systematic review of 23 studies published between 2003-2007, however, reported that very few studies had objectively evaluated simulation education outcomes (Harder 2010). A systematic review of simulation studies in nursing in 2010 found that four of nine experimental studies reported significantly higher post-intervention mean knowledge scores compared with a control group (Cant and Cooper 2010). Weaver (2011) also reported improved knowledge and satisfaction of nursing students in a review of high fidelity simulation. Yuan et al. (2012) in a systematic review of 26 quantitative studies found evidence for improved knowledge and skills. Overall results, however, were mixed, with the conclusion that there was a lack of evidence on the effect on learning owing to varied designs and methods, and small sample sizes.

Given the escalation of simulation programs in nursing curricula, a re-examination of simulation-based learning, it's outcomes, and the validity of assessment measures is timely, to report the current state of the art.

\section{THE REVIEW}

\section{$\underline{\operatorname{Aim}}$}

The study aimed to review current evidence for the effectiveness of medium to high fidelity simulation as an educational strategy in pre-licensure (pre-registration) nursing education. The research questions to be addressed are: (i) in what clinical learning environments is simulation being used in the education of pre-licensure nursing students? (ii) what measures are used to assess learner impact? And (iii) how effective is simulation-based learning? - also 
using knowledge tests as a key statistical outcome measure. Medium and high fidelity simulation environments are described in Box 1.

\section{$\underline{\text { Design }}$}

This paper presents a 'state-of-the-art' review (Grant and Booth 2009) utilizing recent qualitative, quantitative and mixed methods studies. A state-of-the-art review aims to comprehensively and systematically search the current literature in order to report the state of current knowledge and to identify priorities for future investigation and research (Grant and Booth 2009). This design was chosen as the most applicable to identify the effectiveness of simulation in pre-licensure nursing.

\section{$\underline{\text { Search strategy }}$}

Multiple searches were conducted to identify English language studies published during the six years (2010-2015). This period was chosen to maintain the currency of data and to provide an update on the authors' previous review of the literature (anonymized for review2010). The expanded Cumulative Index to Nursing and Allied Health Literature (CINAHL Plus) and PubMed were searched for the period January 2010 to December 2015. PubMed was selected as a key index of over 25 million biomedical citations. Free text searches were also made to broaden the search. Google Scholar was also searched from 2014 - 2015 as it lists the most recent papers and those 'in press'. Reference tracking was conducted and a hand search was made of key related journals such as Clinical Simulation in Nursing to enable a broad search of all applicable journals and to limit publication bias (Greenhalgh and Peacock 2005).

The main search terms based on medical subject headings were 'nursing student'; 'baccalaureate'; 'education, nursing'; 'education, methods'; 'learning'; 'teaching'; 'patient simulation'; and 'human simulation'. Systematic review studies and studies labelled 
'integrative review' (a variation on systematic review), and meta-analysis were also included. An example of a search strategy is given in the supplementary file, Table A

The titles and abstracts of all the identified studies were collected in a library database and then filtered to select those that met the inclusion criteria (given below). Studies were analysed and synthesized using the integrative review process described by Whittemore and Knapfl (2005), in order to answer the research questions.

\section{$\underline{\text { Search outcome }}$}

From 400 studies, we retained peer-reviewed studies that reported primary or secondary research in nursing using medium to high fidelity simulation (Box 1) that described an impact on participant skills or knowledge. The studies selected included active participation of learners in simulation events, such as goal-based role-play with instructor feedback (Cant and Cooper 2010). Studies were excluded if they were asynchronous or information-giving alone.

Studies were also excluded where centred upon post-graduate students or qualified nurses, advanced practice nurses or midwives, or specialty courses such as paediatrics. Other studies were excluded based on research design including direct comparisons with dissimilar modes of education (such as classroom based learning), a topic which has been explored exponentially (Cook et al., 2011) and if there were no simulation intervention outcome data. Also excluded were sub-specialty topics such as simulation pre-briefing, debriefing, learning theory, faculty viewpoints, and interprofessional staff simulation groups. Studies where the full article was not available in English were excluded as were interprofessional research, curriculum planning and design, descriptive or opinion papers, and dissertations. The process for selecting included studies is shown in Figure 1. 


\section{$\underline{\text { Synthesis }}$}

Citations were initially screened by title and studies were rejected if inclusion criteria were not met (Figure 1). The remaining records were screened using the title and abstract, or abstract and full text, whence further studies were included or rejected as applicable. There were a number of selection rounds as further publications were identified and at each stage two authors independently confirmed study eligibility.

A mapping process was then undertaken to classify the studies by research design, curriculum topic, sample, simulation intervention, measures used, and learning outcomes. The characteristics of each record were collated to allow a comparison. Two researchers collaborated to read the full-texts to extract studies with data suitable for a meta-analysis. As the overall aim was to explore the 'state of the art' of simulation in nursing student education all eligible studies were initially retained and classified without excluding any study on the basis of quality.

\section{$\underline{\text { Meta-analysis }}$}

A meta-analysis was conducted to combine study results and to improve the precision of the overall effect measured in the population (Field 2013). The variable 'clinical knowledge' which was the most common objective test result, was chosen as the outcome. This issue was important as there is no consensus among the discipline regarding the impact of simulation on knowledge. Eight studies that provided sufficient knowledge data (eg, number of correct answers out of a series of questions) from repeated pre- and post- tests of the intervention group were included in the analysis. The pre- and post-test mean and standard deviation were extracted from each study. These were used to estimate the mean change in knowledge (and standard error (Borenstein 2009)), post intervention in each study. The mean change was the summary statistic used in the meta-analysis. 
The data were meta-analysed using a random effects model (DerSimonian and Laird 1986), which assumes each study is estimating a different effect, but that each effect comes from the same underlying distribution of effects. A forest plot shows the individual study effects and the overall pooled random effect. Heterogeneity amongst studies was measured using the I-squared statistic (Higgins et al., 2003). Analysis was conducted using STATA vs14 (StataCorp 2015).

In order to describe current applications and review the evidence for use of simulation in nursing education, the context and characteristic of each study are described below. Reporting, where possible, followed guidance provided in the PRISMA checklist for reporting systematic reviews and meta-analysis (Moher et al., 2009).

\section{RESULTS}

The 72 included primary and secondary studies comprised 43 quantitative studies, 13 qualitative studies, and 16 reviews of literature published between 2011 and 2015. A list of the quantitative studies is given in Table 1; the qualitative studies in Table 2 and reviews of literature in Table 3. These studies help to describe the broad range of curriculum topics and research designs incorporating simulation-based education interventions conducted in nursing student education over the last six years.

The research designs in the primary studies comprised various levels of research evidence when assessed according to The Johanna Briggs Institute (2014) definitions of research effectiveness. They included Level 1 randomized controlled trials, Level 2 quasiexperimental studies that analysed pre-test and post-test measures, and Level 3 observationalanalytic designs such as cohort studies with a control group. In this way the impact of the simulation-based learning on the intervention group was reported and gathered as evidence, with the comparison group of less importance. 
Eleven of 43 studies were quantitative experimental or pseudo-randomised participant trials. Several studies provided Level 4 evidence; descriptive-observational designs with a post-intervention measure such as participant feedback; a survey of confidence or satisfaction. Of 16 reviews of literature, nine were systematic reviews and three included a meta-analysis. However, as the component research was mainly quasi-experimental the reviews provided Level 2 evidence.

Sample sizes that varied in quantitative studies from 16 to 409 nursing students, appeared to be limited by the size of pre-registration nursing student cohorts enrolled in any particular course; eg., 116 first year students, 83 third year students. Or, for example, a sample which used a historical comparison group of 154 participants. Studies with larger participant samples recruited students from more than one university or from more than one course. Overall the various sample selection processes were clearly reported.

\section{The simulated learning environments}

In answer to the research question: (i) in what nurse education domains and learning environments is simulation being used? - we describe findings below.

The primary studies were conducted within the pre-qualifying undergraduate or prelicensure nursing students' curriculum. Most reports featured high fidelity face-to-face simulation in laboratory settings using computerized full-body manikins. Several studies reported use of medium fidelity simulation with a manikin and use of a facilitator's voice and generally small groups of student learners worked together as a team. Several studies used a simulated patient (actor), and for some, a student played the patient actor role. Nearly all studies measured impact on the individual 'active' simulation participant, many with students working as a team of four or six. Several studies justified the 'observer' role as 
learning, or as an added experience in addition to active participation (Lippe and Heather 2015, Shelestak et al., 2015, White et al., 2013, Flaathen et al., 2015, Mould et al., 2011).

Following simulation education best practice protocols (Clinical Simulation in Nursing 2013), simulation programs provided multi-modal ways of learning. They generally consisted of a pre-briefing, followed by the simulation and ending with a group discussion, or debrief. Three studies reported use of computer-based interactive simulation approaches where students learned independently rather than in a group (Bogossian et al., 2015, Farra et al., 2013, Johnson et al., 2014) and received as a substitute, textual rather than face-to-face feedback.

Table 1 and Table 2 present summary details of primary simulation studies together with their research focii. By far the most common context of simulation-based learning designs was clinical skills acquisition, including beginning students learning about a single clinical technique (such as blood pressure management or blood transfusion skills) (Gordon et al., 2013, Flood and Higbie 2015), or for senior students more advanced skills such as assessment and management of a rapidly deteriorating patient (Bogossian et al., 2013, 2015, Stayt et al., 2015, Unsworth et al., 2012, Liaw et al., 2012).

Table 3 presents a summary of the literature review studies, the most common research focus $(n=6)$ being evaluations of the delivery of simulation as education. Additionally, use of simulation to improve patient safety competence, as a substitute for clinical practice, and to improve clinical performance, were reviewed. Fourteen of 16 reviews reported a positive impact of simulation for their various focii (see Table 3).

The second common research foci aimed to understand the pedagogy of 'simulation as learning'. These primary studies assessed the impact of the simulation intervention on learners and on various aspects of their educational advancement. For example, knowledge and critical thinking (Shinnick and Woo 2013), or aspects of simulation as learning (Ko and 
Kim 2014, Kim et al., 2015, Graham and Atz 2015, Ewertsson et al., 2015, Kelly and Fry 2013). Learners developed a greater awareness of patient safety using simulation (Kelly and Fry 2013); clinical skills laboratories formed a bridge for students between university and clinical practice (Ewertsson et al., 2015) but HFS experiences can act as a barrier to learning for a minority of students (Graham and Atz 2015).

However, simulation was also reported to statistically significantly improve selfefficacy in experimental and in pretest-posttest designs, according to a meta-analysis (Franklin 2014). Although this and other meta-analysis studies reported some positive outcomes for improved self-efficacy and for cognitive and psychomotor domains of learning (Lee and Oh 2015, Vincent et al., 2015), the meta-analyses were constrained by varied research designs and the use of non-experimental designs. This range of heterogeneous studies therefore limits the overall evidence. In all, 16 reviews of simulation literature presented a broad range of research focii (Table 3 ).

Many of the qualitative studies (see Table 2) explored simulation as learning and the perceived impact and value to students. From the findings, it was apparent that simulation can be applied to a wide range of clinical learning topics with positive evaluations. Beginning students should be orientated to simulation as a technique, and coached in repeated role-plays to become confident at working together in small groups.

\section{Measures of learning impact}

To summarize the research question: 'What instruments/measures were utilized to assess learner impact?', we first refer to recent reviews of nursing literature that gathered and critiqued overall evidence (Table 3). There was a lack of consensus on how to measure 'learning;' as no single measure incorporated all the desired knowledge, attitude, and competency elements. The reviews pointed towards a variety of measures as the measure being used to address the research objective and the academic theme under investigation. 
The measures used in the reviewed primary studies (Table 1) varied between objective measures that were independent of the individual learner (clinical observation, knowledge tests, etc) to more subjective self-reports such as confidence, self-efficacy and satisfaction. Some studies tried to capture levels of clinical skill through self-assessment: eg., Self Report Competency Scores (Stayt et al., 2015), Nurse Decision-Making Instrument (Loke 2014), or the Healthcare Professionals Patient Safety Assessment (Mariani 2015). Others used a validated attitude scale such as a 'self-efficacy' measure that could indicate confidence to achieve a future clinical goal - for example, the General Perceived SelfEfficacy Scale (Stayt et al., 2015). Studies also used a validated course evaluation scale such as the Satisfaction with Simulation Experience Scale (Kim et al., 2014), or Student Satisfaction and Self-confidence in Learning Scale (Fabro 2014). Many studies, however, used purposely developed measures with little or no justification of their rigour. Very few instruments were used repeatedly in different studies, making direct comparison difficult.

The most objective measures are knowledge tests and clinical observations made by a trained observer using a checklist- such as an Objective Structured Clinical Examination (OSCE) (Cant et al., 2012). In a RCT examining the impact of manikin-based simulation to teach nursing students how to recognise and manage a deteriorating patient, Stayt et al. (2015) administered a pre-test OSCE and the same OSCE was repeated as a post-test for both the control and intervention groups. In this way, the authors were able to objectively measure any improvement in clinical performance and also directly compare groups. Positive gains were reported through the use of this definitive measure and other measures.

Some studies usefully examined performance 'at a distance' using objective ratings of performance from retrospective video review of simulated scenarios (Jeong 2015). Other web-based e-simulation studies collected participant data using online surveys and tracked keyboard movements that were downloaded for analyses (Bogossian et al., 2015). 
Importantly, however, it should be noted that time in simulation (or 'dose' of learning) may be a confounding factor among these studies. The 'dose' of simulation experienced by students varied from one hour, to one day, and longer (eg, a 45hr course unit). Thus, study comparisons may need to evaluate the effect of simulation dose on outcomes.

Furthermore, assessment timing and skills retention impact research outcomes. The timing of assessments in the reviewed studies' designs varied greatly, especially between pretest and post-test. The most common measure was the immediate impact with outcomes tested before, and again immediately after, the simulation intervention. Some examples of this design were: Bogossian et al., 2013, Fluharty et al., 2012, Gibbs et al., 2014, Liaw et al., 2012, Lippe and Heather 2015, Roh et al., 2013.

Several studies, however, recognized the need to assess knowledge retention and clinical impact, reassessing knowledge weeks or months later. Gordon et al. (2013) tested the impact of simulation education using HFS with a manikin on students' blood pressure measurement accuracy. In addition to pre- and post simulation measurements, observed accuracy was tested after a further 40 hours of clinical placement experience, thus acknowledging a contribution made by practice experience. A randomized trial teaching nursing students cardiac arrhythmias tested knowledge at baseline, after the intervention, and after a further three months, showing that the simulation group had significantly greater knowledge and better retained knowledge (Tubaishat and Tawalbeh 2014). Further, Hart et al. (2012), studied educational gains in a 45hr structured course curriculum at pre-test, midway through the course, and as a post-test. These strategies have the potential to add rich data to what is known about transfer of knowledge into practice. Delayed testing or serial testing was uncommon, however.

These studies demonstrated that simulation enhances gains in psychomotor skills (Vincent et al., 2015) and volitional qualities such as self-confidence (Mager and Campbell 
2013, Fluharty et al., 2012, Stayt et al., 2015) and satisfaction (Foronda et al., 2013). In addition, a key objective measure was knowledge gained through simulation interventions, which was flagged as an essential measure in 11 studies of the 17 that tested knowledge.

In order to provide empirical evidence we asked the third research question: (iii) how effective is simulation-based learning? - using knowledge tests as the key denominator. A meta-analysis was conducted to answer this question.

\section{Meta-analysis outcome}

The individual study effects and the overall pooled random effect are shown in Table 4. A diamond represents the combined estimate and its 95\% confidence interval. All eight studies showed a gain in knowledge from baseline scores, with a mean overall weighted difference of +5.0 (CI: 3.25-6.82) points on a knowledge measure.

The mean difference varied from 0.62 in a study with 16 participants who completed 10-item knowledge questionnaires (White et al., 2013), to 13.62 where 48 participants completed 37-item knowledge surveys (Hart et al., 2014). (Supplementary file B presents test-retest study details). An estimate of variability (heterogeneity) made between the studies showed a p-value $<0.05$ suggesting evidence of heterogeneity and the random effects model was appropriate. Heterogeneity was also quantified using the I-squared measure (Higgins et al. 2003) which revealed a high $I^{2}$ measure $(98.6 \% ; p=0.000)$ suggesting high heterogeneity. As a guide to interpreting the $\mathrm{I}^{2}$ value, $50 \%$ to $90 \%$ : may represent substantial heterogeneity; $75 \%$ to 100\%: considerable heterogeneity. The weighted results, however, indicated an average gain in knowledge in 652 students across all eight studies after the simulation intervention.

No correlation was found between knowledge effect and simulation duration in the seven studies that conducted simulation education over two, four or six hrs $(\mathrm{p}=0.180)$. 


\section{DISCUSSION}

This study reviewed 72 studies of simulation-based learning in nursing to explore and explain the current state of the art. There were positive outcomes for learning and objective evidence of knowledge gains across the student population, with a weighted mean difference in scores across meta-analysed studies of +5.0 points. Although differences in length of knowledge surveys may have contributed to variability between studies (as a larger number of question items can allow for greater change in knowledge scores) all eight studies demonstrated positive gains after the intervention. The strength of these results should be interpreted with caution, however, because of differences in study designs (heterogeneity) and lower levels of evidence (with few experimental or controlled studies). As simulation is often a mandatory component of nursing education, educators and learners alike should be aware of the impact of simulation education program outcomes, including their differences.

How to best evaluate learning in simulation programs is still perplexing, however. Systematic reviews aim to combine data from different sources to produce overall results from all the data. This study identified that evaluation comprised a mix of subjective and objective measures, and few measures were shared across primary studies, making overall comparison difficult. Other than knowledge tests, before-and-after data reports on other measures were too few to conduct further pooled outcome analyses. A common thread exists in nursing simulation literature, whereby studies aim to measure a host of different variables. A recent review of literature reported that simulation studies in nursing measured around 14 different cognitive effects (Cant and Cooper, 2016). Another review of simulation literature examining psychomotor skills found that six different appraisal tools were used in eight studies in the review (Vincent et al., 2015). Use of so many different outcome measures in the field limits the number of studies that can be pooled to statistically identify small and medium effects which may not be perceptible in one study alone (Cant and Cooper, 2016). 
Further, the validity and reliability (reproducibility) of study results is under question owing to the common use of untested assessment instruments. For example, OSCE instruments may have been based on each institution's preference or format rather than a common tool. In the reviewed studies, very few used the same instrument, thus making collective outcomes difficult to assess. We reported most study outcomes individually. Use of published instruments and scales that have been validated is important to develop a strong culture of evaluation in the nursing literature on simulation (Kardong-Edgren 2010.

Further, we noted that nearly all the reviewed studies took a short-term view of learning by measuring learning outcomes before, and then directly after, the education intervention. Several studies did assess knowledge retention and clinical impact by reassessing knowledge some weeks, or months, later (Gordon, 2013; Hart et al. 2012; Tubaishat and Tawalbeh 2014). These longitudinal designs are key to our understanding of how skills rehearsed in the simulation laboratory can transfer into clinical practice, and should be more commonly reported.

Evidence shows that simulation programs are costly and very time-consuming to develop (Lapkin 2011; Cant and Cooper 2015). A strength of this study is the wide range of curriculum topics seen in the designs used and in the incorporated scenarios, which create a potential resource for other institutions. It should be noted that there is an online collection of simulation scenarios and resources: SIM-one SIM Scenario Exchange ${ }^{\mathrm{TM}}$ (http://www.simone.ca/scenario) as a valuable resource for educators and technicians alike. There are also commercial subscription simulation resources which have the benefit of being well authenticated (eg, Laerdal education resources http://www.laerdal.com/au/docid/27318271/Educational-Services) and others (Cant and Cooper 2015). 
The research evidence for simulation use in nursing education is increasing exponentially. A limitation of this study is that included research was limited to publications in English, while researchers in other countries are known to be publishing simulation research, especially China, Korea, and Spain. Although a broad search for literature was made, and also repeated searches that aimed to limit search bias, it was thus not possible to include all published studies.

In summary, studies with larger samples are needed to present evidence of effect and this could be achieved by combining university nursing cohorts and applying the same curriculum/simulation programs. In research (as opposed to clinical simulation education program assessments), objective measures such as knowledge tests and observation of performance are the most important and valid measures. There is currently an opportunity to use standardized simulation scenarios/evaluations and to utilize a large cohort of students participating in different countries, which would provide high quality evidence.

\section{CONCLUSION}

The review represents the current state of the art of simulation in nursing education in English-speaking nations. It explored current educational practices, with the primary studies conducted between 2010 and 2015. Subjective measures (self-reported confidence, perceived competence) when used alone, as in many studies, reduce the rigor of the findings. Other than knowledge tests, objectively rated measures (eg, a trained observer with checklist) were used by few. These studies, however, present valid empirical evidence and larger studies are needed to verify the findings. For example, objective evidence of positive knowledge outcomes was identified in a meta-analysis across a combined sample of 652 participants. In future research, a move to utilize higher level designs (eg., experimental studies) with use of validated assessment tools can add more weight to evidence for the positive impact of simulation-based learning in nursing student education. Overall, the simulation programs 
used in pre-licensure nursing curricula demonstrate innovation and excellence. These programs should be shared across the discipline to facilitate development of multimodal learning for both pre-licensure and postgraduate nurses. 


\section{References}

Berndt, J., 2014. Patient safety and simulation in prelicensure nursing education: An integrative review. Teaching and Learning in Nursing 9, 16-22.

Blum, C. A., Parcells, D. A., 2012. Relationship between high-fidelity simulation and patient safety in prelicensure nursing education: A comprehensive review. Journal of Nursing Education 51, 429-435.

Bogossian, F., Cooper, S., Cant, R., Beauchamp., A, Kain., V, Porter, J., Bucknall, T. Phillips, M., 2013. Undergraduate nursing students' performance in recognising and responding to sudden patient deterioration in high fidelity simulated environments: Quantitative results from an Australian multi-centre study. Nurse Education Today 34, 691-696. DOI : 10.1016/j.nedt.2013.09.015.

Bogossian, F. E., Cooper, S. J., Cant, R., Porter, J. Forbes, H., 2015 A trial of e-simulation of sudden patient deterioration (FIRST2ACT WEB) on student learning. Nurse Education Today 35, e36-e42.

Borenstein, M., Hedges, L., Higgins, J. Rothstein, H., 2009. Introduction to Meta Analysis, John Wiley and Sons, New York.

Cant, R. P., Cooper, S. J., 2010. Simulation-based learning in nurse education: systematic review. Journal of Advanced Nursing 66, 3-15.

Cant, R., Cooper, S., 2015. The time is right for Web-based clinical simulation programs in nursing education. Journal of Nursing Education and Practice 5, 113-119.

Cant, R. P., Cooper, S. J., 2016. Use of simulation-based learning in undergraduate nursing education: An umbrella systematic review. Nurse Education Today 49: 63-71. Doi:

http://dx.doi.org/10.1016/j.nedt.2016.11.015

Cant, R., McKenna, L., Cooper, S., 2012. Assessment of clinical competence of pre-registration nursing students: a systematic review of objective measures. International Journal of Nursing Practice 19, 163-176. DOI: 10.1111/ijn.12053.

Clinical Simulation In Nursing (2013) Standards of Best Practice: Simulation. Clinical Simulation in Nursing 9, 6:ii-iii.

Cook, D., Hatala, R., Brydges, R., Zendejas, B., Szostek, J., Wang, A., 2011. Technology-enhanced simulation for health professions education a systematic review and meta-analysis. Journal of the American Medical Association 306, 978-988.

Cook, N. F., McAloon, T., O'Neill, P. Beggs, R., 2012. Impact of a web based interactive simulation game (PULSE) on nursing students' experience and performance in life support training- a pilot study. Nurse Education Today 32, 714-720. doi: 10.1016/j.nedt.2011.09.013.

DerSimonian, R., Laird, N., 1986. Meta-analysis in clinical trials. Controlled Clinical Trials 7, 177188. 
Diaz, D. A., Maruca, A. T., Kuhnly, J. E., Jeffries, P. Grabon, N., 2015. Creating caring and empathic nurses: a simulated ostomate. Clinical Simulation in Nursing 11, 513-518.

Drake, S. A., Ayers, C. J., 2013. Introducing forensic nursing concepts within an interprofessional unexpected and non-natural end-of-life simulation. Clinical Simulation in Nursing 9, e579e583.

Dzioba, J., Cant, R., Cooper, S., Bogossian, F. Phillips, N. M., 2014. Barriers and enablers to learning during team-based clinical simulations: Reflective interviews with final year undergraduate nursing students. Journal of Nursing Education and Practice 4, 32. DOI: 10.5430/jnep.v4n10p32

Eikeland Husebø, S.I., Bjørshol, C. A., Rystedt, H., Friberg, F. Søreide, E., 2012. A comparative study of defibrillation and cardiopulmonary resuscitation performance during simulated cardiac arrest in nursing student teams. Scandinavian Journal of Trauma, Resuscitation and Emergency Medicine 20, 1. http://www.sjtrem.com/content/20/1/23.

Evans, C. B., Mixon, D. K., 2015. The evaluation of undergraduate nursing students' knowledge of a post-op pain management after participation in simulation. Pain Management Nursing 16, 930-937.

Ewertsson, M., Allvin, R. E., Holmstrom, I. K., Blomberg, K., 2015. Walking the bridge: Nursing students' learning in clinical skill laboratories. Nurse Education in Practice 15, 277-283.

Fabro, K., Schaffer, M., Scharton, J., 2014. The development, implementation, and evaluation of an end-of-life simulation experience for baccalaureate nursing students. Nursing Education Perspectives 35, 19-25.

Farra, S., Miller, E., Timm, N., Schafer, J., 2013. Improved training for disasters using 3-D virtual reality simulation. Western Journal of Nursing Research 35, 655-671.

Felton, A., Holliday, L., Ritchie, D., Langmack, G., Conquer, A., 2013. Simulation: A shared learning experience for child and mental health pre-registration nursing students. Nurse Education in Practice 13, 536-540.

Field, A., 2013. Discovering Statistics Using IBM SPSS Statistics. [4 ${ }^{\text {th }}$ edition] Sage, London.

Fisher, D., King, L., 2013. An integrative literature review on preparing nursing students through simulation to recognize and respond to the deteriorating patient. Journal of Advanced Nursing 69, 2375-2388. doi: 10.1111/jan.12174.

Flaathen, E.K., Flo, J., Fagerström, L., 2015. Students' evaluation of a computerized patient simulator in nursing education and its effect on the results of preclinical tests. Journal of Nursing Education and Practice 5, 1-9. DOI: 10.5430/jnep.v5n7p1

Flood, L. S., Higbie, J., 2016. A comparative assessment of nursing students' cognitive knowledge of blood transfusion using lecture and simulation. Nurse Education in Practice 16, 8-13. 
Fluharty, L., Hayes, A., Milgrom, L., Malarney, K., Smith, D., Reklau, M., Jeffries, P. McNelis, A., 2012. A multisite, multi-academic track evaluation of end-of-life simulation for nursing education. Clinical Simulation in Nursing 8, e135-e143.

Foronda, C., Liu, S., Bauman, E. B., 2013. Evaluation of simulation in undergraduate nurse education: an integrative review. Clinical Simulation in Nursing 9, e409-e416.

Franklin, A., Lee, A., 2014. Effectiveness of simulation for improvement in self-efficacy among novice nurses: a meta-analysis. Journal of Nursing Education 53, 607-614. DOI: 10.3928/01484834-20141023-03 •

Gibbs, J., Trotta, D., Overbeck, A., 2014. Human patient simulation versus case study: Which teaching strategy is more effective in teaching nursing care for the hypoglycemic patient? Teaching and Learning in Nursing 9, 59-63.

Gillan, P. C., Jeong, S., van der Riet, P. J., 2014. End of life care simulation: a review of the literature. Nurse Education Today 34, 766-774. doi: 10.1016/j.nedt.2013.10.005.

Gordon, C. J., Frotjold, A., Fethney, J., Green, J., Hardy, J., Maw, M., Buckley, T., 2013. The effectiveness of simulation-based blood pressure training in preregistration nursing students. Simulation in Healthcare 8, 335-340.

Graham, C. L., Atz, T., 2015. Baccalaureate minority nursing students' perceptions of high-fidelity simulation. Clinical Simulation in Nursing 11, 482-488.

Grant, M., Booth, A., 2009. A typology of reviews: an analysis of 14 review types and associated methodologies. Health Information and Libraries Journal 26, 91-108. doi: 10.1111/j.14711842.2009.00848.x.

Greenhalgh, T., Peacock, R., 2005. Effectiveness and efficiency of search methods in systematic reviews of complex evidence: audit of primary resources. British Medical Journal 331, 10641065 .

Harder, N., 2010. Use of simulation in teaching and learning in health sciences: a systematic review. Journal of Nursing Education 49, 22-28. doi.org/10.3928/01484834-20090828-08

Hart, P. L., Brannan, J. D., Long, J. M., Maguire, M. B., Brooks, B. K., Robley, L. R., 2014. Effectiveness of a structured curriculum focused on recognition and response to acute patient deterioration in an undergraduate BSN program. Nurse Education in Practice 14, 30-36. doi: 10.1016/j.nepr.2013.06.010.

Higgins, J.P., Thompson, S.G., Deeks, J.J., Altman, D.G., 2003. Measuring inconsistency in metaanalyses. BMJ 327, 557-560.

Hober, C., Bonnel, W., 2014. Student perceptions of the observer role in high-fidelity simulation. Clinical Simulation in Nursing 10, 507-514.

Jeong, H., 2015. Analyze of nursing performance ability using a simulation-based program. International Journal of Bio-Science and Bio-Technology 7, 107-114 http://dx.doi.org/10.14257/ijbsbt.2015.7.6.12. 
Johnson, M. P., Hickey, K. T., Scopa-Goldman, J., Andrews, T., Boerem, P., Covec, M., Larson, E., 2014. Manikin versus web-based simulation for advanced practice nursing students. Clinical Simulation in Nursing 10, e317-e323.

Kardong-Edgren, S., Adamson, K.A., Fitzgerald, C., 2010. A review of currently published evaluation instruments for human patient simulation. Clinical Simulation in Nursing 6, e25-e35.

Kelly, M. A. and Fry, M., 2013. Masters nursing students' perceptions of an innovative simulation education experience. Clinical Simulation in Nursing 9, e127-e133.

Khalaila, R., 2014. Simulation in nursing education: An evaluation of students' outcomes at their first clinical practice combined with simulations. Nurse Education Today 34, 252-258.

Kim, K. H., Lee, A., Avila, S., Ouyang, A., Walker, A., 2015. Application of high fidelity simulation for acquisitions of nursing skills: nursing students' perspective. International Journal for Innovation Education and Research 3, 1.

Kimhi, E., Reishtein, J. L., Cohen, M., Friger, M., Hurvitz, N., Avraham, R., 2014. Impact of simulation and clinical experience on self-efficacy in nursing students: intervention study. Nurse Educator 41, E1-E4.

Kirkman, T. R., 2013. High fidelity simulation effectiveness in nursing students' transfer of learning. International Journal of Nursing Education Scholarship 10, 171-176. doi: 10.1515/ijnes-20120009 .

Ko, E., Kim, H. Y., 2014. Effects of multi-mode simulation learning on nursing students' critical thinking disposition, problem solving process, and clinical competence. Korean Journal of Adult Nursing 26, 107-116.

Lapkin, S., Levett-Jones, T., Bellchambers, H., Fernandez, R., 2010. Effectiveness of patient simulation manikins in teaching clinical reasoning skills to undergraduate nursing students: a systematic review. Clinical Simulation in Nursing 6, e207-e222.

Lapkin, S., Levett-Jones, T., 2011. A cost-utility analysis of medium vs. high-fidelity human patient simulation manikins in nursing education. Journal of Clinical Nursing 20, 3543-3552.

Larue, C., Pepin, J., Allard, Ã., 2015. Simulation in preparation or substitution for clinical placement: A systematic review of the literature. Journal of Nursing Education and Practice 5, 132.

Lee, J., Oh, P. J., 2015. Effects of the use of high-fidelity human simulation in nursing education: a meta-analysis. Journal of Nursing Education 54, 501-507.

Lee, S. J., Kim, S. S., Park, Y-M., 2014. First experiences of high-fidelity simulation training in junior nursing students in Korea. Japan Journal of Nursing Science 12, 222-231.

Levett-Jones, T., McCoy, M., Lapkin, S., Noble, D., Hoffman, K., Dempsey, J., Arthur, C., Roche, J., 2011. The development and psychometric testing of the Satisfaction with Simulation Experience Scale. Nurse Education Today 31, 705-710. 
Liaw, S. Y., Koh, Y., Dawood, R., Kowitlawakul, Y., Zhou, W.,Lau, S. T., 2014. Easing student transition to graduate nurse: A SIMulated Professional Learning Environment (SIMPLE) for final year student nurses. Nurse Education Today, 34, 349-355.

Liaw, S. Y., Scherpbier, A., Rethans, J.-J., Klainin-Yobas, P., 2012. Assessment for simulation learning outcomes: A comparison of knowledge and self-reported confidence with observed clinical performance. Nurse Education Today 32, e35-e39.

Lindsey, P. L., Jenkins, S., 2013. Nursing students' clinical judgment regarding rapid response: the influence of a clinical simulation education intervention. Nursing Forum 48, 61-70.

Lippe, M. P., Heather, B., 2015. improving attitudes and perceived competence in caring for dying patients: an end-of-life simulation. Nursing Education Perspectives 36, 372-378.

Loke, J., Lee, B.K., Noor, A. M., Loh, S., 2014. High fidelity full sized human patient simulation manikins: Effects on decision making skills of nursing students. Journal of Nursing Education and Practice 4, 31.

Luctkar-Flude, M., Wilson-Keates, B., Larocque, M., 2012. Evaluating high-fidelity human simulators and standardized patients in an undergraduate nursing health assessment course. Nurse Education Today 32, 448-452. doi: 10.1016/j.nedt.2011.04.011

Mager, D. R., Campbell, S. H., 2013. Home care simulation for student nurses: Medication management in the home. Nurse Education Today 33, 1416-1421.

Mariani, B., Cantrell, M.A., Meakim, C., Jenkinson, A., 2015. Improving students' safety practice behaviors through a simulation-based learning experience. Journal of Nursing Education 54, S35-38.

McCaughey, C. S., Traynor, M. K., 2010. The role of simulation in nurse education. Nurse Education Today 30, 827-832.

McClimens, A., Lewis, R., Brewster, J., 2012. The anatomy lesson of Dr Nicolaes Tulp: what can it teach us today? Journal of Intellectual Disabilities 16, 17-27.

Moher, D., Liberati, A., Tetzlaff, J., Altman, D.G., 2009. Preferred reporting items for systematic reviews and meta-analyses: the PRISMA statement. Annals of Internal Medicine 151, 264269.

Moreland, S., Lemieux, M., Myers, A., 2012. End-of-life care and the use of simulation in a baccalaureate nursing program. International Journal of Nursing Education Scholarship 9, 116. doi: $10.1515 / 1548-923 X .2405$.

Motola, I., Devine, L., 2013. Simulation in healthcare education: A best evidence practical guide. AMEE Guide No. 82. Medical Teacher 35, e1511-e1530.

Mould, J., White, H., Gallagher, R., 2011. Evaluation of a critical care simulation series for undergraduate nursing students. Contemporary Nurse 38, 180-190. 
Najjar, R. H., Lyman, B., Miehl, N., 2014. Nursing students' experiences with high-fidelity simulation. International Journal of Nursing Education Scholarship 12, 27-35. DOI: 10.1515/ijnes-2015-0010

O'Boyle-Duggan, M., Grech, J. D., Brandt, R., 2012. Effectiveness of live simulation of patients with intellectual disabilities. Journal of Nursing Education 51, 334-342.

Oh, P.-J., Jeon, K. D., Koh, M. S., 2015. The effects of simulation-based learning using standardized patients in nursing students: A meta-analysis. Nurse Education Today 35, e6-e15 DOI: http://dx.doi.org/10.1016/j.nedt.2015.01.019.

Piscotty, R., Grobbel, C., Tzeng, H. M., 2011. Integrating quality and safety competencies into undergraduate nursing using student-designed simulation. Journal of Nurse Education 50:429436. doi: 10.3928/01484834-20110429-04

Reid-Searl, K., Happell, B., Vieth, L., Eaton, A., 2012. High Fidelity Patient Silicone Simulation: A qualitative evaluation of nursing students' experiences. Collegian 19, 77-83.

Ricketts, B., 2011. The role of simulation for learning within pre-registration nursing education - a literature review. Nurse Education Today 31, 650-654. doi: 10.1016/j.nedt.2010.10.029

Ricketts, B., Clair, M., Louise, S., 2013. Simulated practice learning in a preregistration programme. British Journal of Nursing 21, 435-440.

Roh, Y. S., 2014. Effects of High-fidelity patient simulation on nursing students' resuscitation-specific self-efficacy. Computers Informatics Nursing 32, 84-89.

Roh, Y. S., Lee, W. S., Chung, H. S., Park, Y. M., 2013. The effects of simulation-based resuscitation training on nurses' self-efficacy and satisfaction. Nurse Education Today 33, 123-128.

Ross, J. G., 2012. simulation and psychomotor skill acquisition: a review of the literature. Clinical Simulation in Nursing 8, e429-e435.

Schlairet, M. C. S., James, T., Sauls, D. H., Bellflowers, L., 2015. Cognitive load, emotion, and performance in high-fidelity simulation among beginning nursing students: A pilot study. Journal of Nursing Education 54, S5-11.

Secomb, J., McKenna, L., Smith, C., 2012. The effectiveness of simulation activities on the cognitive abilities of undergraduate third-year nursing students: a randomised control trial. Journal of Clinical Nursing 21, 3475-3484.

Sharpnack, P. A., Goliat, L., Baker, J. R., Rogers, K., Shockey, P., 2013. Thinking like a nurse: using video simulation to rehearse for professional practice. Clinical Simulation in Nursing 9, e571e577.

Shearer, J. E., 2013. High-fidelity simulation and safety: an integrative review. Journal of Nursing Education 52, 39-45. doi:http://dx.doi.org/10.3928/01484834-20121121-01 
Shelestak, D.S., Meyers, T.W., Jarzembak, J.M., Bradley, E., 2015. A process to assess clinical decision-making during human patient simulation: a pilot study. Nursing Education Perspectives 36, 185-187.

Shinnick, M. A., Woo, M. A., 2013. The effect of human patient simulation on critical thinking and its predictors in prelicensure nursing students. Nurse Education Today 33, 1062-1067.

Skrable, L., Fitzsimons, V., 2014. Simulation in associate degree nursing education: a literature review. Teaching and Learning in Nursing 9, 120-125.

StataCorp, 2015. Stata Statistical Software: Release 14. StataCorp LP., College Station, Texas.

Stayt, L. C., Merriman, C., Ricketts, B., Morton, S., Simpson, T., 2015. Recognizing and managing a deteriorating patient: a randomized controlled trial investigating the effectiveness of clinical simulation in improving clinical performance in undergraduate nursing students. Journal of Advanced Nursing 71, 2563-2574.

Stroup, C., 2014. Simulation usage in nursing fundamentals: integrative literature review. Clinical Simulation in Nursing 10, e155-e164.

The Joanna Briggs Institute and University of Adelaide, 2014. New JBI Levels of Evidence. At: http://joannabriggs.org/assets/docs/approach/JBI-Levels-of-evidence_2014.pdf, University of Adelaide.

Tubaishat, A., Tawalbeh, L. I., 2014. Effect of cardiac arrhythmia simulation on nursing students' knowledge acquisition and retention. Western Journal of Nursing Research 37, 1160-1174.

Unsworth, J., McKeever, M., Kelleher, M., 2012. Recognition of physical deterioration in patients with mental health problems: the role of simulation in knowledge and skill development. Journal of Psychiatric and Mental Health Nursing 19, 536-545.

Vincent, M. A., Sheriff, S., Mellott, S., 2015. The efficacy of high-fidelity simulation on psychomotor clinical performance improvement of undergraduate nursing students. Computers Informatics Nursing 33, 78-84.

Weaver, A., 2011. High-fidelity patient simulation in nursing education: an integrative review. Nursing Education Perspectives 32, 37-40. doi: http://dx.doi.org/10.5480/1536-5026-32.1.37.

White, A., Brannan, J., Long, J., Kruszka, K., 2013. Comparison of instructional methods: cognitive skills and confidence levels. Clinical Simulation in Nursing 9, e417-e423.

Whittemore, R., Knafl, K., 2005. The integrative review: updated methodology. Journal of Advanced Nursing 52, 546-553.

Yuan, H. B., Williams, B. A., Fang, J. B., 2014. The contribution of high-fidelity simulation to nursing students' confidence and competence: a systematic review. International Nursing Review 59, 26-33.

Yuan, H. B., Williams, B. A., Fang, J. B., Ye, Q. H., 2012. A systematic review of selected 
evidence on improving knowledge and skills through high-fidelity simulation. Nurse Education Today 32, 294-298 
Table 1: Summary of included quantitative studies

\begin{tabular}{|c|c|c|c|c|c|c|}
\hline Study & $\begin{array}{l}\text { Design and } \\
\text { Target group }\end{array}$ & $\begin{array}{l}\text { Simulation } \\
\text { topic }\end{array}$ & $\begin{array}{l}\text { Methods-sample, simulation } \\
\text { type, duration }\end{array}$ & Measurement variable & Results & Outcome \\
\hline $\begin{array}{l}\text { Bogossian et al } \\
2013\end{array}$ & $\begin{array}{l}\text { Quasi-experimental } \\
\text { prospective trial } \\
\text { Final year Nursing } \\
\text { students }\end{array}$ & $\begin{array}{l}\text { Adult hospital } \\
\text { patient } \\
\text { deterioration }\end{array}$ & $\begin{array}{l}\text { One group prospective trial in labs with } \\
97 \text { final year nursing students and } \\
\text { simulated patient (actor), over } 3 \\
\text { scenarios ( } 2 \text { hrs total) }\end{array}$ & $\begin{array}{l}\text { Knowledge, satisfaction, } \\
\text { observed clinical performance } \\
\text { scores (OSCE) }\end{array}$ & $\begin{array}{l}\text { Pass rate for performance was low }(1 \%), \\
\text { and situation awareness of team leaders } \\
\text { was low }(41 \%) \text {. }\end{array}$ & $\begin{array}{l}\text { Final year nursing students have difficulty in } \\
\text { managing a deteriorating patient and further } \\
\text { rehearsal is required. }\end{array}$ \\
\hline $\begin{array}{l}\text { Bogossian et al. } \\
2015\end{array}$ & $\begin{array}{l}\text { Quasi-experimental } \\
\text { prospective trial - } \\
\text { final year Nursing } \\
\text { students (year 3) }\end{array}$ & $\begin{array}{l}\text { Hospital patient } \\
\text { deterioration }\end{array}$ & $\begin{array}{l}\text { Convenience sample } n=367 \text { students } \\
\text { completed Web-based interactive } \\
\text { simulations via computer screen \& } \\
\text { evaluation surveys (approx } 1.5 \mathrm{hrs} \text { ) }\end{array}$ & $\begin{array}{l}\text { Knowledge, satisfaction, } \\
\text { objective clinical scores }\end{array}$ & $\begin{array}{l}38.1 \% \text { achieved a pass in clinical } \\
\text { performance across three scenarios; a } \\
\text { pass in clinical knowledge increased from } \\
78 \% \text { pre-simulation to } 92 \% \text { post- } \\
\text { simulation }(M=7.63 \pm 1.52 ; M=8.68 \pm 1.50 ; \\
p=0.000),\end{array}$ & $\begin{array}{l}\text { FIRST2ACTWeb effectively enhanced } \\
\text { knowledge, } \\
\text { Virtual clinical performance, and self- } \\
\text { assessed knowledge, skills, confidence, and } \\
\text { competence. }\end{array}$ \\
\hline Cook et al. 2012 & $\begin{array}{l}\text { Quasi-experimental } \\
\text { study of senior year } \\
\text { Nursing students }\end{array}$ & $\begin{array}{l}\text { Life support } \\
\text { training }\end{array}$ & $\begin{array}{l}\text { Two-group prospective study A web } \\
\text { based interactive simulation game } \\
\text { Platform for Life support (PULSE) was } \\
\text { trialed by } 34 \text { students ( } 18 \text { in } \\
\text { intervention group, } 14 \text { controls ) }\end{array}$ & $\begin{array}{l}\text { Quantitative performance } \\
\text { assessment; questionnaire } \\
\text { assessing the learning } \\
\text { experience. }\end{array}$ & $\begin{array}{l}\text { A statistically significant difference was } \\
\text { found between the competence the } \\
\text { groups displayed. }\end{array}$ & $\begin{array}{l}\text { PULSE was positively evaluated as an } \\
\text { educational tool when used alongside } \\
\text { traditional life support training. }\end{array}$ \\
\hline $\begin{array}{l}\text { Eikeland Husebø } \\
\text { et al. 2012) }\end{array}$ & $\begin{array}{l}\text { Comparative study } \\
\text { of defibrillation and } \\
\text { CPR performance } \\
\text { of nursing student } \\
\text { teams }\end{array}$ & CPR & $\begin{array}{l}\text { Observational study using a manikin; } \\
\text { performance of } 28 \text { nursing student } \\
\text { teams. }\end{array}$ & $\begin{array}{l}\text { Time to defibrillation, } \\
\text { performance according to D- } \\
\text { CPR-algorithm in a simulated } \\
\text { cardiac arrest }\end{array}$ & $\begin{array}{l}\text { None of the nursing student teams } \\
\text { achieved top scores on the D-CPR- } \\
\text { checklist. }\end{array}$ & $\begin{array}{l}\text { More time must be assigned for repetitive } \\
\text { practice of CPR and reflection. }\end{array}$ \\
\hline $\begin{array}{l}\text { Evans and Mixon } \\
2015\end{array}$ & $\begin{array}{l}\text { Undergraduate } \\
\text { Nursing Students' } \\
\text { Knowledge of Post- } \\
\text { op Pain } \\
\text { Management after } \\
\text { Participation in } \\
\text { Simulation }\end{array}$ & $\begin{array}{l}\text { Knowledge of } \\
\text { post-op pain } \\
\text { management }\end{array}$ & $\begin{array}{l}\text { One-group observational study of } 117 \\
\text { junior year nursing students using HFS } \\
\text { with manikin, working in a team. }\end{array}$ & $\begin{array}{l}\text { Knowledge and Attitudes of } \\
\text { Survey Regarding Pain } \\
\text { (KASRP) instrument. }\end{array}$ & $\begin{array}{l}\text { Percent correct score was } 70.4 \%, S D \\
8.6 \% \text { based on } 37 \text { items in KASRP. }\end{array}$ & $\begin{array}{l}\text { Sim scenarios that include pain management } \\
\text { are an innovative way to prepare student for } \\
\text { their primary nursing role. }\end{array}$ \\
\hline Fabro 2014 & $\begin{array}{l}\text { Descriptive study of } \\
\text { baccalaureate } \\
\text { nursing students }\end{array}$ & $\begin{array}{l}\text { Principles of } \\
\text { palliative care } \\
\text { and } \\
\text { communication } \\
\text { for the dying } \\
\text { patient. }\end{array}$ & $\begin{array}{l}\text { One-group observational study of } 25 \\
+33 \text { nursing students (over } 2 \text { years) in } \\
\text { a palliative care course who completed } \\
2 \text { end of life simulations using HFS with } \\
\text { manikin, working in a team of 5-6 } \\
\text { students. }\end{array}$ & $\begin{array}{l}\text { 16-item Educational Practices } \\
\text { questionnaire, 13-item } \\
\text { Student Satisfaction and Self- } \\
\text { confidence in Learning Scale }\end{array}$ & $\begin{array}{l}\text { Student mean score of Self-confidence } \\
\text { was } 4.4 / 5 \text {, for Education Practices } \\
\text { (satisfaction) } M=4.5 / 5 \text {. Thematic analysis } \\
\text { of comments was reported }\end{array}$ & $\begin{array}{l}\text { End of life simulation is an effective } \\
\text { capstone learning experience for } \\
\text { nursing students. }\end{array}$ \\
\hline Farra et al. 2013 & $\begin{array}{l}\text { Experimental two } \\
\text { group repeated } \\
\text { measures study of } \\
\text { Second year } \\
\text { associate Nursing } \\
\text { students }\end{array}$ & $\begin{array}{l}\text { Disaster training } \\
\text { 3-D virtual } \\
\text { scenarios (VRS) }\end{array}$ & $\begin{array}{l}\text { randomized sample }(n=54) \text { using } \\
\text { Avatars in Second Life in purposely } \\
\text { developed scenario }\end{array}$ & $\begin{array}{l}\text { Knowledge pretest and post- } \\
\text { test ( } 20 \text {-question } M C Q \text { pre- } \\
\text { test and at } 2 \text { months after)( }\end{array}$ & $\begin{array}{l}\mathrm{N}=41 \text { completed all surveys. Effect of } \\
\text { virtual simulation was strongly significant } \\
(\mathrm{p}<0.001) \text {, (simulation group } \mathrm{M}= \\
13.5 \pm 2.52 ; \mathrm{M}(\mathrm{T} 2)=17.68 \pm 1.73 ; 80 \% \\
\text { gave positive comments about the VRS. }\end{array}$ & $\begin{array}{l}\text { VRS is an instructional method that reinforces } \\
\text { learning and improves learning retention. }\end{array}$ \\
\hline $\begin{array}{l}\text { Flaathen and Flo } \\
2015\end{array}$ & $\begin{array}{l}\text { Quasi-experimental } \\
\text { study of first year } \\
\text { Nursing students }\end{array}$ & $\begin{array}{l}\text { Clinical care } \\
\text { scenarios }\end{array}$ & $\begin{array}{l}\text { Case study: evaluation of impact of } \\
\text { HFS with manikin; } n=158 \text { students }\end{array}$ & Preclinical test of knowledge. & $\begin{array}{l}\mathrm{N}=76 \text { students described impact of } \\
\text { simulation either as observer or as active } \\
\text { nurse assistant, with significant }\end{array}$ & $\begin{array}{l}\text { Active participation in sim is beneficial and } \\
\text { can assist students to pass a clinical test. }\end{array}$ \\
\hline
\end{tabular}




\begin{tabular}{|c|c|c|c|c|c|c|}
\hline & & & & & $\begin{array}{l}\text { differences in preclinical test results } \\
\text { between groups }(p<.05) \text {. (test results not } \\
\text { reported) }\end{array}$ & \\
\hline $\begin{array}{l}\text { Flood and Higbie } \\
2015\end{array}$ & $\begin{array}{l}\text { Quasi-experimental } \\
\text { study BSN Nursing } \\
\text { students }\end{array}$ & $\begin{array}{l}\text { Blood transfusion } \\
\text { skills }\end{array}$ & $\begin{array}{l}\text { Prospective comparison trial }(n=86) \\
\text { with intervention group receiving a } \\
\text { didactic-lecture prior to simulation } \\
\text { ( } n=44 \text { ) or no lecture group ( } n=42) \text { (both } \\
\text { groups completed simulation working in } \\
\text { groups of } 6-8 \text { students over } 2 \mathrm{hrs} \text { ). }\end{array}$ & Cognitive knowledge & $\begin{array}{l}\text { Overall pre-test scores improved } \\
\text { significantly after simulation }(7.06 \pm 1.65 ; \\
9.13 \pm 1.00) \text { although the lecture group had } \\
\text { higher scores on both prêt-test and post- } \\
\text { test }(p=0.000)\end{array}$ & $\begin{array}{l}\text { Use of HFS after a related lecture may help } \\
\text { increase students' knowledge. }\end{array}$ \\
\hline $\begin{array}{l}\text { Fluharty et al } \\
2012\end{array}$ & $\begin{array}{l}\text { Quasi-experimental } \\
\text { trial, Nursing } \\
\text { students in various } \\
\text { courses }\end{array}$ & End of life care & $\begin{array}{l}\text { Quasi-experimental prospective trial; } \\
\text { impact of HFS with mannikin for } 336 \\
\text { nursing students working in teams (20- } \\
\text { min simulation over } 1 \text { hour program) }\end{array}$ & $\begin{array}{l}\text { 10-question purposely } \\
\text { developed Knowledge survey, } \\
\text { 30-item Self-Confidence in } \\
\text { Caring for a Dying Patient in } \\
\text { Nursing; End of Life } \\
\text { Communication Assessment } \\
\text { Tool. Satisfaction survey. }\end{array}$ & $\begin{array}{l}\text { Knowledge }(n=329) \text { was significantly } \\
\text { improved across all students regardless of } \\
\text { role in simulation }(M=8.01, M=9.18 \text {; } \\
t=15.29, p=0.000) \text { although differences } \\
\text { were seen by background of group. }\end{array}$ & $\begin{array}{l}\text { Findings support simulation as a strong and } \\
\text { viable pedagogical approach to learning. }\end{array}$ \\
\hline Gibbs et al 2014 & $\begin{array}{l}\text { Quasi-experimental } \\
\text { trial using first year } \\
\text { associaite degree } \\
\text { Nursing students }\end{array}$ & Hypoglycaemia & $\begin{array}{l}\text { Prospective two-group comparison trial } \\
(\mathrm{n}=96) \text { students working in teams of } \\
\text { five, with low fidelity manikin and } \\
\text { instructor voice compared with a case } \\
\text { study (scenario, group discussion). }\end{array}$ & $\begin{array}{l}\text { 10-question hypoglycaemia } \\
\text { knowledge survey (MCQ), } \\
\text { simulation satisfaction, plus } \\
\text { instructor- completed clinical } \\
\text { evaluation tool. }\end{array}$ & $\begin{array}{l}\text { Pretest scores } 55 \% \text { improved significantly } \\
\text { in the simulation group to } 68 \% \text { although } \\
\text { improvement was higher in the case study } \\
\text { group }(55 \% ; 80 \% ; f(1,92)=4.44, p=.04) \text {. } \\
\text { Clinical scores for the simulation group } \\
\text { were significantly higher of the two (17/22 } \\
\text { versus } 8 / 22 ; p<.001)\end{array}$ & $\begin{array}{l}\text { The studies validated two teaching methods } \\
\text { for teaching hypoglycaemia nursing } \\
\text { interventions. }\end{array}$ \\
\hline $\begin{array}{l}\text { Gordon et al } \\
2013\end{array}$ & $\begin{array}{l}\text { Randomized trial } \\
\text { with first year pre- } \\
\text { registration Nursing } \\
\text { students }\end{array}$ & $\begin{array}{l}\text { Blood pressure } \\
\text { measurement } \\
\text { accuracy }\end{array}$ & $\begin{array}{l}\text { Randomized prospective comparison } \\
\text { trial with laboratory learning group or } \\
\text { intervention: } 2 \text {-hr simulation group with } \\
\text { HPS. (accuracy was tested after further } \\
40 \text { hrs of clinical hospital practice) }\end{array}$ & $\begin{array}{l}10 \text { yes/no questions on } \\
\text { knowledge of correct B P } \\
\text { measurement procedures; } \\
\text { Confidence and technical } \\
\text { ability; delayed expert } \\
\text { observation of skills while } \\
\text { measuring B P on live patient. }\end{array}$ & $\begin{array}{l}\text { B P accuracy was not significantly } \\
\text { different between controls and intervention } \\
\text { group. }(p>.05)\end{array}$ & $\begin{array}{l}\text { Accuracy of B P taking was not enhanced by } \\
\text { use of patient simulator although confidence } \\
\text { was reported as improved. }\end{array}$ \\
\hline Hart et al 2014 & $\begin{array}{l}\text { Quasi-experimental } \\
\text { study of, BSN } \\
\text { Nursing students }\end{array}$ & $\begin{array}{l}\text { Recognition and } \\
\text { response to acute } \\
\text { patient } \\
\text { deterioration }\end{array}$ & $\begin{array}{l}\text { Mixed methods design repeated } \\
\text { measures \& descriptive, qualitative } \\
\text { approach with } 48 \text { BSN students after a } \\
\text { structured } 45 \text {-hour unit, simulations } \\
\text { used HFS. (manikins). }\end{array}$ & $\begin{array}{l}\text { Purposely developed } 37 \text {-item } \\
\text { knowledge survey, Self- } \\
\text { confidence Scale, rating of } \\
\text { Teamwork using TEAM } \\
\text { instrument; guided reflective } \\
\text { session(GRS) }\end{array}$ & $\begin{array}{l}\text { Knowledge scores improved significantly } \\
(67.0 \pm 6.66 \text { to mid } 80.62 \pm 7.34 p=<.001 \text {, to } \\
\text { post-intervention } 88.70 \pm 6.48 p=<.001 \text {. } \\
\text { A significant effect was found on } \\
\text { teamwork as scores increased at mid and } \\
\text { post intervention }(p<.01) \text {. Self-confidence } \\
\text { improved throughout the course ( } p< \\
.001) \text {. }\end{array}$ & $\begin{array}{l}\text { Simulation training is effective in preparing } \\
\text { BSN students to recognize and respond to } \\
\text { critical events. }\end{array}$ \\
\hline Jeong 2015 & $\begin{array}{l}\text { Quasi-experimental } \\
\text { study with junior } \\
\text { Nursing students }\end{array}$ & $\begin{array}{l}\text { Hypoglycaemia, } \\
\text { respiratory } \\
\text { distress }\end{array}$ & $\begin{array}{l}\text { Prospective trial of simulation by topic } \\
\text { ( } 55 \text { teams of hypoglycaemia and } 70 \\
\text { teams of respiratory distress } \\
\text { syndrome); after preparation, each } \\
\text { student working in team of } 3 \text { using HFS } \\
\text { (SimMan) over } 25 \text { mins. } \\
\end{array}$ & $\begin{array}{l}\text { Observed performance (video } \\
\text { analysis) rated on checklist }\end{array}$ & $\begin{array}{l}\text { The hypoglycaemia scenario achieved } \\
\text { significantly higher overall scores through } \\
\text { points for 'preparation', 'assessment' and } \\
\text { 'intervention'. }\end{array}$ & $\begin{array}{l}\text { Rapid escalation of symptoms in the } \\
\text { respiratory syndrome made it harder for } \\
\text { student to manage. Repetitive simulation is } \\
\text { necessary }\end{array}$ \\
\hline Khailala 2014 & $\begin{array}{l}\text { Quasi-experimental } \\
\text { descriptive study of } \\
\text { second-year nursing } \\
\text { students }\end{array}$ & $\begin{array}{l}\text { Preparation for } \\
\text { first clinical } \\
\text { practice }\end{array}$ & $\begin{array}{l}\mathrm{N}=61 \text { students' sim experiences to } \\
\text { reduce anxiety and increase } \\
\text { confidence. }\end{array}$ & $\begin{array}{l}\text { 20-item State-Trait Anxiety } \\
\text { Inventory to measure, } \\
\text { anxiety; self-confidence, } \\
\text { satisfaction }\end{array}$ & $\begin{array}{l}\text { Anxiety scores decreased, (M1.80 } \pm 0.35 ; \\
1.71 \pm 0.35, p=0.02) \text { while self-confidence } \\
\text { and caring ability scores increased after } \\
\text { using simulations.. }\end{array}$ & $\begin{array}{l}\text { The use of simulations before and during } \\
\text { nursing students' first clinical practice is a } \\
\text { useful and effective learning strategy. }\end{array}$ \\
\hline
\end{tabular}




\begin{tabular}{|c|c|c|c|c|c|c|}
\hline Kim et al 2015 & $\begin{array}{l}\text { Quasi-experimental } \\
\text { descriptive study of } \\
\text { Nursing students }\end{array}$ & $\begin{array}{l}\text { Clinical skills } \\
\text { acquisition }\end{array}$ & $\begin{array}{l}\text { Evaluation of } 186 \text { culturally diverse } \\
\text { students' perceptions of nursing skills } \\
\text { acquisition using } 2 \text { three-hour HFS } \\
\text { sessions in curriculum with post-test }\end{array}$ & $\begin{array}{l}21 \text { item Simulation Evaluation } \\
\text { Questionnaire, develop by } \\
\text { authors }\end{array}$ & $\begin{array}{l}\text { Positive scores were achieve din the } \\
\text { survey, in the range } 1-1.5 \text { indicating strong } \\
\text { agreement. Results were not pre-tested as } \\
\text { overall scores }\end{array}$ & $\begin{array}{l}\text { Students valued HFS as an effective medium } \\
\text { for improving their clinical skill acquisitions. }\end{array}$ \\
\hline Kimhi et al 2014 & $\begin{array}{l}\text { Randomised trial } \\
\text { using Nursing } \\
\text { students }\end{array}$ & $\begin{array}{l}\text { Fundamentals of } \\
\text { Nursing process }\end{array}$ & $\begin{array}{l}\text { Randomised double crossover trial of } \\
\text { medium fidelity sim } \pm \text { mannikins ( } 3 \\
\text { days) versus clinical experience ( } 5 \\
\text { days) \& self-efficacy in } 56 \text { second } \\
\text { semester BSN students. }\end{array}$ & $\begin{array}{l}\text { Short form ( } 7 \text { items) Self } \\
\text { Confidence/Self-efficacy for } \\
\text { the Nursing Process Scale }\end{array}$ & $\begin{array}{l}\text { Simulation increased self-confidence/self- } \\
\text { efficacy for both groups at time } 0 \text { and time } \\
2 \text { ( } t=-9.02, p=.01 \text {, effect size }=.54) \text {. }\end{array}$ & $\begin{array}{l}\text { Simulation increased self-confidence/self- } \\
\text { efficacy equivalently whether timed either } \\
\text { before or after clinical experience. }\end{array}$ \\
\hline Kirkman 2013 & $\begin{array}{l}\text { Time series design } \\
\text { with Nursing } \\
\text { students }\end{array}$ & $\begin{array}{l}\text { Respiratory } \\
\text { assessment }\end{array}$ & $\begin{array}{l}\text { Observational ratings of students' } \\
\text { respiratory patient assessment prior to } \\
\text { lecture, after lecture, and after clinical } \\
\text { simulation }\end{array}$ & $\begin{array}{l}\text { Purposely developed 12-point } \\
\text { 'OSCE' with ratings assessed } \\
\text { by nurse educators }\end{array}$ & $\begin{array}{l}\text { Difference in Mean score T1 to T2 was - } \\
1.571 \text {; between T2 and T3 (simulation } \\
\text { intervention) was significantly greater (- } \\
1.746)(p=0.000)\end{array}$ & $\begin{array}{l}\text { Transfer of learning' into bedside } \\
\text { management was confirmed with HFS }\end{array}$ \\
\hline Ko and Kim 2014 & $\begin{array}{l}\text { Quasi-experimental } \\
\text { trial with non- } \\
\text { equivalent control } \\
\text { group and junior } \\
\text { Nursing students }\end{array}$ & $\begin{array}{l}\text { Emergency and } \\
\text { critical care } \\
\text { nursing (patient } \\
\text { with abdo } \\
\text { pain/malaena) }\end{array}$ & $\begin{array}{l}\text { A trial of simulation education } \\
\text { (treatment group } n=33,32 \text { controls in } \\
\text { subsequent year) }(4 \text { hrs multi-modal } \\
\text { simulation learning using standardized } \\
\text { patient/students in teams of } 4 .\end{array}$ & $\begin{array}{l}27 \text {-item Critical thinking } \\
\text { Disposition Scale; } 25 \text {-item } \\
\text { problem solving scale, } 19 \text { - } \\
\text { item modified scale on clinical } \\
\text { competence. }\end{array}$ & $\begin{array}{l}\text { No difference between groups in Critical } \\
\text { thinking disposition; significant } \\
\text { improvement in Problem Solving process } \\
\text { for sim group }(+0.32 \text { points vs }+0.03 \\
\text { points, }(\mathrm{t}=-2.39, \mathrm{p}=.020) \text {. Clinical } \\
\text { competence scores increased significantly } \\
\text { more in the sim group }(3.49 \pm 0.43 \text { to } \\
3.78 \pm 0.42)(\mathrm{F}=12.76 . \mathrm{p}=.001) \text {. }\end{array}$ & $\begin{array}{l}\text { Multi-modal simulation is an effective method } \\
\text { to improve clinical competence of students } \\
\text { However, result variables were self-reported } \\
\text { by students, hence further research is } \\
\text { needed to independently measure outcomes }\end{array}$ \\
\hline Lee et al 2015 & $\begin{array}{l}\text { Quasi-experimental } \\
\text { descriptive study of } \\
\text { Junior nursing } \\
\text { students }\end{array}$ & Nursing care & $\begin{array}{l}\text { Mixed methods survey of students re } \\
\text { first sim experience }(n=33) \text { plus } \\
\text { reflective journals }(n=18) ; \text { using HFS } \\
\text { (SimMan) in half-day program. }\end{array}$ & $\begin{array}{l}\text { 13-item Simulation } \\
\text { Effectiveness for Learning } \\
\text { scale translated into Korean }\end{array}$ & $\begin{array}{l}\text { Students gave mainly positive ratings of } \\
\text { simulation items. Qualitative themes } \\
\text { were machine-human interactions, } \\
\text { learning capability and reconciling practice } \\
\text { with theory. }\end{array}$ & $\begin{array}{l}\text { Further research is needed to develop } \\
\text { simulation experiences in junior students and } \\
\text { give more time to learning. }\end{array}$ \\
\hline Liaw et al 2012 & $\begin{array}{l}\text { Randomised } \\
\text { controlled trial with } \\
\text { senior Nursing } \\
\text { students }\end{array}$ & $\begin{array}{l}\text { Physiological } \\
\text { deterioration }\end{array}$ & $\begin{array}{l}\text { RCT }(\mathrm{N}=31) \text { of intervention of } 6 \text {-hr four } \\
\text { scenario simulation-based program (in } \\
\text { teams of } 6 \text { students) using HFS vs no } \\
\text { intervention for controls. }\end{array}$ & $\begin{array}{l}\text { Baseline observed one- } \\
\text { simulation performance using } \\
31 \text {-item checklist (RAPIDS) } \\
\text { for all; pretest post-test } \\
\text { surveys of knowledge (53 } \\
\text { items MCQ), and confidence } \\
\text { ( } 5 \text { items). Videoed simulation } \\
\text { performances were rated. }\end{array}$ & $\begin{array}{l}\text { Intervention group significantly improved } \\
\text { knowledge score }(t=9.60 ; p<0.001) \text {, } \\
\text { performances }(t=9.26 ; p=<0.001) \text { and } \\
\text { self-confidence }(t=3.19 ; p=<0.001) \text {, with } \\
\text { greater effect than for control group. }\end{array}$ & $\begin{array}{l}\text { Knowledge and self-confidence did not } \\
\text { predict simulation performance. Simulation } \\
\text { based assessment of self confidence could } \\
\text { lead to overestimation of self-confidence }\end{array}$ \\
\hline Liaw, et al 2014 & $\begin{array}{l}\text { Quasi-experimental } \\
\text { descriptive study of } \\
\text { final year student } \\
\text { nurses }\end{array}$ & $\begin{array}{l}\text { Clinical Ward } \\
\text { practices }\end{array}$ & $\begin{array}{l}\text { Descriptive study of } 94 \text { final year } \\
\text { student nurses in } 15 \text {-hour SIMPLE } \\
\text { (Simulated Professional Learning } \\
\text { Environment) program with multiple } \\
\text { simulation scenarios (HFS) based on } \\
\text { actual ward clinical practices. }\end{array}$ & $\begin{array}{l}\text { Perceived preparedness for } \\
\text { clinical practice questionnaire; } \\
\text { Satisfaction survey }\end{array}$ & $\begin{array}{l}\text { Post test ' 'preparedness' improved from } \\
M=96.86 \pm 15.08 \text { to } M=117.21 \pm 15.17(\mathrm{t}= \\
12.06 ; \mathrm{p}=0.01) \text {, with high satisfaction } \\
\text { reported with qualitative themes. }\end{array}$ & $\begin{array}{l}\text { SIMPLE program enhances nursing students' } \\
\text { preparedness for transition to graduate } \\
\text { nursing practice. }\end{array}$ \\
\hline $\begin{array}{l}\text { Lindsay and } \\
\text { Jenkins } 2013\end{array}$ & $\begin{array}{l}\text { Randomized } \\
\text { experimental trial of } \\
\text { senior nursing } \\
\text { students (final } \\
\text { semester) } \\
\end{array}$ & $\begin{array}{l}\text { Clinical judgment } \\
\text { responding to } \\
\text { rapid } \\
\text { deterioration: }\end{array}$ & $\begin{array}{l}\text { Non-equivalent controlled trial of } n=40 \\
\text { intervention, } n=39 \text { controls re rapid } \\
\text { response and Code blue practices over } \\
\text { one simulation day (working in groups } \\
\text { of 3-4) }\end{array}$ & $\begin{array}{l}\text { 11-item knowledge survey of } \\
\text { rapid response systems; } \\
\text { Intervention sim group had }\end{array}$ & $\begin{array}{l}\text { Post test scores for intervention group } \\
\text { improved from } M=61.07 \pm 17.09 \text { to } \\
M=90.91 .21 \pm 8.73 \text {. which was higher than } \\
\text { the scores for controls }\end{array}$ & $\begin{array}{l}\text { Clinical simulation can be used to enhance } \\
\text { clinical judgment. }\end{array}$ \\
\hline $\begin{array}{l}\text { Lippe and Becker } \\
2015\end{array}$ & $\begin{array}{l}\text { Quasi-experimental } \\
\text { descriptive study of } \\
\text { Nursing students }\end{array}$ & $\begin{array}{l}\text { End of life care } \\
\text { for critically ill } \\
\text { patient }\end{array}$ & $\begin{array}{l}\text { Pre-test post-test design testing } \\
\text { attitudes and perceived competence in } \\
\text { 2-hour lab simulation with } N=128 \\
\text { students ( } 3 \text { cohorts) in teams of } 8-10,\end{array}$ & $\begin{array}{l}\text { 15-item Perceived } \\
\text { Competence in Meeting } \\
\text { ELNLC Standards survey; 10- } \\
\text { item Concerns About Dying }\end{array}$ & $\begin{array}{l}\text { Perceived competence was significantly } \\
\text { improved at post-test form a baseline of } \\
\geq 3.5 \text { to } \geq 4.0 \text { ( } p=<0.01) \text {. FATCOD scores } \\
\text { did not change over time. }\end{array}$ & $\begin{array}{l}\text { Students' perceived competence in caring for } \\
\text { patient at end of life increased after } \\
\text { simulation }\end{array}$ \\
\hline
\end{tabular}




\begin{tabular}{|c|c|c|c|c|c|c|}
\hline & & & $\begin{array}{l}\text { participating/playing family member or } \\
\text { observing }\end{array}$ & $\begin{array}{l}\text { Scale; 30-item Frommelt } \\
\text { Attitudes Toward Care of the } \\
\text { Dying (FATCOD) Scale. }\end{array}$ & & \\
\hline Loke et al 2014 & $\begin{array}{l}\text { Quasi-experimental } \\
\text { study of second year } \\
\text { Nursing students }\end{array}$ & $\begin{array}{l}\text { Decision-making } \\
\text { process. }\end{array}$ & $\begin{array}{l}\text { Cross-sectional survey }(\mathrm{n}=232) \text { to } \\
\text { determine factors related to simulation } \\
\text { that influence students' development of } \\
\text { a decision making process (after at } \\
\text { least } 4 \text { hrs of HF-HPSM simulation } \\
\text { labs) }\end{array}$ & $\begin{array}{l}\text { 24-item Nurse Decision } \\
\text { Making Instrument; effect of } \\
\text { debriefing }\end{array}$ & $\begin{array}{l}\text { A complete simulation experience of role- } \\
\text { playing followed by active discussion in } \\
\text { debrief was a significant contributor to the } \\
\text { decision making process ( } t=73.6667 ; \\
p<0.005) \text {. Active participation in debrief } \\
\text { independently predicted development of } \\
\text { decision-making ( } t=12.633 ; p<.005)\end{array}$ & $\begin{array}{l}\text { Active participation in debrief was more } \\
\text { important than role-playing in developing } \\
\text { decision-making process. }\end{array}$ \\
\hline $\begin{array}{l}\text { Luctkar } \\
\text { Flude,2015 }\end{array}$ & $\begin{array}{l}\text { Randomized } \\
\text { experimental study } \\
\text { of Nursing students }\end{array}$ & $\begin{array}{l}\text { Unresponsive } \\
\text { patient } \\
\text { assessments }\end{array}$ & $\begin{array}{l}\text { Survey of } 44 \text { students randomized to } \\
\text { respiratory assessment (asthma } \\
\text { exacerbation) on a HFS (voice } \\
\text { assisted), or SP, or Community } \\
\text { Volunteer; }\end{array}$ & $\begin{array}{l}\text { Self-efficacy: } 17 \text {-item Health } \\
\text { Assessment Educational } \\
\text { Modality Evaluation survey } \\
\text { (HAEME) ; performance } \\
\text { checklist; performance time } \\
\text { taken }\end{array}$ & $\begin{array}{l}\text { Self-efficacy scores did not differ across } \\
\text { groups. Performance skills were } \\
\text { significantly greater with HFS (but learners } \\
\text { were less satisified with this modality. }\end{array}$ & $\begin{array}{l}\text { Experiential learning modalities should be } \\
\text { included in an undergraduate nursing health } \\
\text { assessment course. }\end{array}$ \\
\hline $\begin{array}{l}\text { Mager and } \\
\text { Campbell } 2013\end{array}$ & $\begin{array}{l}\text { Randomized } \\
\text { experimental study } \\
\text { of pre-licensure } \\
\text { Nursing students }\end{array}$ & $\begin{array}{l}\text { Medication } \\
\text { management of } \\
\text { electronic record }\end{array}$ & $\begin{array}{l}\text { Intervention group ( } \mathrm{n}=28 \text { ) had lab } \\
\text { simulation options over } 1 \text { week, } \\
\text { managing medications, pre filling } \\
\text { medications using electronic charts; } \\
\text { controls }(\mathrm{n}=21 \text { ) had traditional (multi- } \\
\text { model) teaching including } \\
\text { demonstration }\end{array}$ & $\begin{array}{l}\text { 10-item knowledge test; } \\
\text { Bandura's self efficacy } \\
\text { instrument was modified to } \\
\text { measure confidence in } \\
\text { students' knowledge and } \\
\text { skills; } 34 \text {-item observational } \\
\text { performance checklist }\end{array}$ & $\begin{array}{l}\text { Self-confidence scores (rated in } 6 \text { items) } \\
\text { improved significantly in intervention group } \\
(\mathrm{M}(\mathrm{n}=28)=4.6 ; \mathrm{M}=8.6, p<0.01 \text { ) with } \\
\text { more effect than for control group. } \\
\text { Knowledge was significantly improved in } \\
\text { the intervention group to } 92 \% \text { (baseline } \\
\text { not given). }\end{array}$ & $\begin{array}{l}\text { Simulation improved nursing students' } \\
\text { knowledge and perceived confidence more } \\
\text { than traditional teaching modalities }\end{array}$ \\
\hline Mariani 2015 & $\begin{array}{l}\text { Non-experimental } \\
\text { descriptive survey of } \\
\text { senior } \\
\text { undergraduate } \\
\text { Nursing students }\end{array}$ & $\begin{array}{l}\text { Patient safety } \\
\text { principles and } \\
\text { practices }\end{array}$ & $\begin{array}{l}\text { Survey of } \mathrm{N}=175 \text { students who, on a } \\
\text { simulation day, viewed } 2 \text { simulation } \\
\text { videos on safety, surveyed safety } \\
\text { features in a patient room, and } \\
\text { debriefed in teams of 6-8. }\end{array}$ & $\begin{array}{l}\text { Healthcare Professionals' } \\
\text { Safety Assessment scale; }\end{array}$ & $\begin{array}{l}\text { Mean scores for Part } 2 \text { ratings of comfort } \\
\text { level to report an error, increase } \\
\text { significantly }(16.95 \pm 3.44 ; 17.69 \pm 3=.25 ; t \\
(n=153)=2.78, p=0.006)\end{array}$ & $\begin{array}{l}\text { Simulation is a teaching strategy that may } \\
\text { contribute to increasing undergraduate } \\
\text { nursing students' comfort with reporting or } \\
\text { investigating errors. }\end{array}$ \\
\hline $\begin{array}{l}\text { Moreland et al. } \\
2012\end{array}$ & $\begin{array}{l}\text { Quasi-experimental } \\
\text { study of junior } \\
\text { undergraduate } \\
\text { Nursing students }\end{array}$ & End-of-life Care & $\begin{array}{l}\text { Descriptive pilot study of } 14 \text { students' } \\
\text { knowledge and self-efficacy in patient } \\
\text { management following a 15-min } \\
\text { simulation (working in pairs) with a lung } \\
\text { cancer 'patient'. }\end{array}$ & $\begin{array}{l}\text { 7-item Knowledge MCQ; 8- } \\
\text { item Self-Efficacy } \\
\text { Assessment Instrument scale } \\
\text { (both purposely developed for } \\
\text { this study) }\end{array}$ & $\begin{array}{l}\text { Post test knowledge scores improved from } \\
M=5.21 \text { to } M=6.0(p=0.003) \text { (t-test used } \\
\text { for } 14 \text { cases!). an } 11 \% \text { increase. Self- } \\
\text { efficacy improved from } M=35.36 \text { to } \\
M=37.79 \text { out of } 48(p=0.05) \text { Students } \\
\text { want to rehearse skills further }\end{array}$ & $\begin{array}{l}\text { Gains in knowledge and self-efficacy indicate } \\
\text { that simulation was a good instructional } \\
\text { technology for teaching end of life nursing } \\
\text { care. }\end{array}$ \\
\hline Mould et al. 2011 & $\begin{array}{l}\text { Quasi-experimental } \\
\text { study of senior BN } \\
\text { Nursing students }\end{array}$ & $\begin{array}{l}\text { Critical nursing } \\
\text { care scenarios }\end{array}$ & $\begin{array}{l}\text { Descriptive study evaluating a } 27 \\
\text { simulation scenario program (with } \\
\text { programmed mannequins, moulage } \\
\text { and actors) over a 9-week semester; } \\
\text { with teams of } 4 \text { students completing } \\
\text { scenarios each week over } 2 \text { hours } \\
\text { (with one team as observers). }(n=219)\end{array}$ & $\begin{array}{l}\text { Confidence and competence } \\
\text { using a 4-item specifically } \\
\text { developed survey and open } \\
\text { comment satisfaction survey. }\end{array}$ & $\begin{array}{l}\text { Perceived confidence scores improved } \\
\text { from } M=2.30 \pm 0.90 \text { to } M=3.75 \pm 0.76 \\
(p<0.001) \text { and competence scores } \\
\text { improved from } M=2.51 \pm 0.88 \text { to } \\
M=3.71 \pm 0.69(p<0.001) \text {. } \\
\text { Average increase in confidence scores } \\
\text { were } 1.45 \text { points (effectively } 63 \%), \\
\text { competence scores } 1.2 \text { points (effectively } \\
48 \%) \text {. Students enjoyed learning }\end{array}$ & $\begin{array}{l}\text { A series of medium-to-high fidelity } \\
\text { simulations over the semester demonstrated } \\
\text { an improvement in BN students' competence } \\
\text { and confidence related to critical care nursing } \\
\text { practice. }\end{array}$ \\
\hline $\begin{array}{l}\text { O'Boyle-Duggan } \\
\text { et al. } 2012\end{array}$ & $\begin{array}{l}\text { Mixed methods } \\
\text { study of Nursing } \\
\text { students }\end{array}$ & $\begin{array}{l}\text { Managing a } \\
\text { patient with } \\
\text { disabilities. }\end{array}$ & $\begin{array}{l}\text { Quasi-experimental prospective study } \\
\text { of } \\
173 \text { health students ( } n=120 \text { nurses) } \\
\text { working in groups of three; each } \\
\text { student participating in } \geq 1 \text { interaction }\end{array}$ & Self-confidence, satisfaction & $\begin{array}{l}\text { Satisfaction with learning was high with } \\
95 \% \text { of responses agree/strongly agree; } \\
\text { self-confidence scores following the } \\
\text { simulation were also hiugh with seven of } 8 \\
\text { items receiving a rating of } 4 \text { or } 5 \text { from } 85 \%\end{array}$ & $\begin{array}{l}\text { Students felt confident and satisfied with the } \\
\text { simulation activity. }\end{array}$ \\
\hline
\end{tabular}




\begin{tabular}{|c|c|c|c|c|c|c|}
\hline & & & $\begin{array}{l}\text { with a simulated patient while facilitator } \\
\& \text { others provided peer reflections; plus } \\
\text { nursing student focus group. }\end{array}$ & & of participants. & \\
\hline $\begin{array}{l}\text { Piscotty et al. } \\
2011\end{array}$ & $\begin{array}{l}\text { Quasi-experimental } \\
\text { study of Nursing } \\
\text { students (4-year BN } \\
\text { and 12-month } \\
\text { accelerated second- } \\
\text { degree BSN) }\end{array}$ & $\begin{array}{l}\text { Integrating quality } \\
\text { and safety } \\
\text { competencies } \\
\text { into } \\
\text { undergraduate } \\
\text { nursing using } \\
\text { simulation }\end{array}$ & $\begin{array}{l}\text { Pretest and posttest design to evaluate } \\
\text { quality and safety knowledge, skills and } \\
\text { attitudes via student-developed } \\
\text { simulation scenario; } 97 \text { BN students } \\
\text { and } 44 \text { BSN. Scenarios were } \\
\text { developed \& filmed by student groups } \\
\text { and presented in class with student-led } \\
\text { debrief. }\end{array}$ & $\begin{array}{l}\text { Knowledge and safety test, } \\
\text { self-efficacy (attitudes to } 6 \\
\text { QSEN competency areas) }\end{array}$ & $\begin{array}{l}\text { Knowledge and safety test scores } \\
\text { increased significantly in both cohorts eg., } \\
\text { Knowledge } p=0.027 \text {, safety } p=0.03 \text {. } \\
\text { BN students' overall: } M=70.83 \pm 8.09 \text {; } \\
M=72.31 \pm 9.65 ; t=-1.69, \text { df } 91, p=0.094) \text {. + } \\
\text { knowledge } M=59.78 \pm 12.02, M= \\
66.12 \pm 12.18, t=-4.94, \text { df } 91, p=0.000 \text {, vs } \\
\text { (accelerated students overall: } \\
M=76.28 \pm 9.91 ; m=78.28 \pm 8.16 ; t=-1.56, \text { df } \\
38, p=0.127) .+ \text { knowledge } \\
M=66.03 \pm 14.61, M=70.51 \pm 14.16, t=- \\
2.29 \text {, df } 38, p=0.027) \text {. }\end{array}$ & $\begin{array}{l}\text { Student-led simulation was effective in } \\
\text { improving students' quality and safety self- } \\
\text { efficacy and knowledge. }\end{array}$ \\
\hline Roh, 2014 & $\begin{array}{l}\text { Quasi-experimental } \\
\text { study of second year } \\
\text { Diploma Nursing } \\
\text { students }\end{array}$ & $\begin{array}{l}\text { Patient } \\
\text { resuscitation }\end{array}$ & $\begin{array}{l}\text { Non-equivalent control group trial } \\
\text { ( } n=163) ; \text { students assigned to medium } \\
\text { fidelity simulator (ResusciAnne) } \\
\text { ( } n=138) \text { or HFS (SimMan) ( } n=28) \text { (all } \\
\text { students previously learned } \\
\text { resuscitation- specific topics during } \\
\text { course) working in teams of } 4 \\
\text { completed cardiac arrest simulation. }\end{array}$ & $\begin{array}{l}\text { 17-item Resuscitation Self- } \\
\text { Efficacy Scale }\end{array}$ & $\begin{array}{l}\text { Overall mean self-efficacy score increased } \\
\text { in high-fidelity group }(t=9.327, P<.001) \\
\& \text { medium-fidelity group }(t=6.568, P< \\
.001) \text {. HFS group reported significantly } \\
\text { higher scores on debriefing \& recording } \\
\text { subscale }(t=5.578, P<.001), \text { responding } \\
\& \text { rescuing subscale }(t=5.811, P<.001), \\
\text { reporting subscale }(t=3.441, P=.001), \& \\
\text { overall scale score }(t=4.737, P<.001) .\end{array}$ & $\begin{array}{l}\text { Simulation-based training has a positive } \\
\text { impact on improving self-efficacy. Additional } \\
\text { high-fidelity simulation is more effective than } \\
\text { medium-fidelity simulation only in improving } \\
\text { nursing students' self-efficacy. There is a } \\
\text { need to boost student' self-efficacy through } \\
\text { mastery experiences in their curriculum. }\end{array}$ \\
\hline $\begin{array}{l}\text { Schlairet et al } \\
2015\end{array}$ & $\begin{array}{l}\text { Quasi-experimental } \\
\text { pilot study of Junior } \\
\text { nursing students }\end{array}$ & $\begin{array}{l}\text { Fundamentals of } \\
\text { nursing clinical } \\
\text { simulations }\end{array}$ & $\begin{array}{l}\text { Descriptive study to explore impact of } \\
\text { simulation (using SimMan) on emotion } \\
\text { and cognitive load ( } n=40) \text {, among } \\
\text { beginning nursing students (working in } \\
\text { groups of } 6 \text { ) in two scenarios. }\end{array}$ & $\begin{array}{l}\text { 8-item Emotion Scale; } \\
\text { Cognitive Load Rating Scale; } \\
\text { 170-item Test of Essential } \\
\text { Academic Skills (TEAS); } 85- \\
\text { item Kaplan Critical Thinking } \\
\text { Test. }\end{array}$ & $\begin{array}{l}\text { No significant effect was found for } \\
\text { cognitive load and odds of correct } \\
\text { assessment performance, although } \\
\text { various data were implicated. }\end{array}$ & $\begin{array}{l}\text { Nursing students demonstrate positive } \\
\text { emotion and high levels of cognitive load } \\
\text { during simulation. Findings may inform better } \\
\text { instructional design for simulation in } \\
\text { beginning nursing students }\end{array}$ \\
\hline $\begin{array}{l}\text { Secomb et al, } \\
2012\end{array}$ & $\begin{array}{l}\text { Randomised } \\
\text { controlled trial of } \\
\text { senior nursing } \\
\text { students }\end{array}$ & $\begin{array}{l}\text { Cognitive load in } \\
\text { Cardiac } \\
\text { scenarios }\end{array}$ & $\begin{array}{l}\text { Pretest post-test parallel control group } \\
\text { ( } N=58 \text { ) to test e-simulation (Micro-Sim } \\
\text { commercial decision making activity, } 2 \\
\text { cardiac scenarios), vs face-to-face } \\
\text { simulation (same scenarios in lab } \\
\text { 'ward' with VitalSim manikin) in } \\
\text { individual students }\end{array}$ & $\begin{array}{l}\text { The 65- item Learning } \\
\text { Environment Preferences } \\
\text { (LEP) inventory; }\end{array}$ & $\begin{array}{l}\text { The was no significant difference in } \\
\text { cognitive gain scores between intervention } \\
\text { ( e-simulation) and control (face-to-face) } \\
\text { groups, although a trend of non-significant } \\
\text { difference in native -English language. }\end{array}$ & $\begin{array}{l}\text { More rigorous research into simulation } \\
\text { activities is required. }\end{array}$ \\
\hline $\begin{array}{l}\text { Sharpnack et al } \\
2013\end{array}$ & $\begin{array}{l}\text { Quasi-experimental } \\
\text { study of BN and } \\
\text { BSN Nursing } \\
\text { students }\end{array}$ & $\begin{array}{l}\text { Teamwork, safety } \\
\text { issues. }\end{array}$ & $\begin{array}{l}\text { A pretest-posttest design, with } \mathrm{N}=54 \\
\text { nursing students to evaluate } \\
\text { assessment, communication, critical } \\
\text { thinking, and technical skills after video } \\
\text { simulation (three cohorts- } 21 \mathrm{BN}, 19 \\
\mathrm{BSN}, 14 \mathrm{BN} \text { ). }\end{array}$ & $\begin{array}{l}\text { 22-item Creighton Simulation } \\
\text { Evaluation Instrument (C-SEI) } \\
\text { to test quality and safety } \\
\text { competence, technical skills, } \\
\text { critical thinking. }\end{array}$ & $\begin{array}{l}\text { Pretest scores improved for all three } \\
\text { groups. (i) } M=7.57 \pm 2.44 ; M=19.24 \pm 0.83 ; \\
t=(n=20)=19.25, p=0.001 ; \text { (ii) } B N \\
\text { (working in pairs) } M=9.14 \pm 2.34 ; \\
M=19.57 \pm 1.90 ; t=(n=6)=5.46, p=0.002 ; \\
\text { (iii) } B S N: M=11.32 \pm 2.85 ; M=15.58 \pm 1.35 \\
t=(n=18)=6.24, p=0.001 \text {. }\end{array}$ & $\begin{array}{l}\text { Student found repeated use of video- } \\
\text { recorded scenario simulations were useful in } \\
\text { applying classroom knowledge to their clinical } \\
\text { practice. }\end{array}$ \\
\hline $\begin{array}{l}\text { Shelastak et al } \\
2015\end{array}$ & $\begin{array}{l}\text { Quasi-experimental } \\
\text { study of Nursing } \\
\text { students }\end{array}$ & $\begin{array}{l}\text { Clinical cues in } \\
\text { cardiac scenarios }\end{array}$ & $\begin{array}{l}\text { Prospective study (pilot) of } 51 \text { students' } \\
\text { recognising critical decision points } \\
\text { during HPS; } 6 \text { simulation session with }\end{array}$ & $\begin{array}{l}\text { Objective Structured Clinical } \\
\text { Examination ()SCE) scores } \\
\text { and written clinical }\end{array}$ & $\begin{array}{l}\text { At Time 1, } 49 \% \text { correctly identified the } \\
\text { situation, at T2 } 71 \% \text {; student who correct } \\
\text { identified the cues were more likely to }\end{array}$ & $\begin{array}{l}\text { Clinical decision making is a complex process } \\
\text { and further research is needed with larger } \\
\text { samples. }\end{array}$ \\
\hline
\end{tabular}




\begin{tabular}{|c|c|c|c|c|c|c|}
\hline & & & $\begin{array}{l}10 \text { students per session (5 in active } \\
\text { role, as observers (all in the same } \\
\text { room). }\end{array}$ & $\begin{array}{l}\text { judgements gathered form } \\
\text { students during pauses in the } \\
\text { scenario }\end{array}$ & make correct or partially correct decisions. & \\
\hline $\begin{array}{l}\text { Shinnick and } \\
\text { Woo, } 2013\end{array}$ & $\begin{array}{l}\text { Quasi-experimental } \\
\text { study of Nursing } \\
\text { students }\end{array}$ & $\begin{array}{l}\text { Patients' fluid } \\
\text { levels }\end{array}$ & $\begin{array}{l}\text { Descriptive study- one group }(n=154) \\
\text { from } 3 \text { schools who had learned the } \\
\text { care of decompensated heart failure } \\
\text { rotated through pre-test in groups of } 5 \\
\text { but individually participated in the } \\
\text { simulation }\end{array}$ & $\begin{array}{l}\text { 12-item HF clinical knowledge } \\
\text { test (pre and post were } \\
\text { different); } 33 \text { item } \\
\text { computerized Health } \\
\text { Sciences Reasoning Test pre } \\
\text { and post to measure critical } \\
\text { thinking; } 12 \text {-item Kolb } \\
\text { Learning Style Inventory }\end{array}$ & $\begin{array}{l}\text { Mean knowledge score improved } 6.5 \\
\text { points }(p<0.001)(T 1 \mathrm{M}=64.87 \pm 12.19) \text {; } \\
\text { but there were no statistical overall gains } \\
\text { in } \mathrm{CT} \text {. Only students who were older age } \\
\text { had gains in } \mathrm{CT} \text {. }\end{array}$ & $\begin{array}{l}\text { Simulation is an effective learning modality } \\
\text { for HF in pre-licensure nursing students. } \\
\text { Optimal preparation and dosing for improved } \\
\text { knowledge are yet to be determined. }\end{array}$ \\
\hline Stayt et al, 2015 & $\begin{array}{l}\text { Randomized } \\
\text { controlled trial with } \\
\text { first year Nursing } \\
\text { students }\end{array}$ & $\begin{array}{l}\text { Recognizing and } \\
\text { managing an } \\
\text { adult } \\
\text { deteriorating } \\
\text { patient in } \\
\text { hospital. } \\
\text { Patient } \\
\text { deterioration }\end{array}$ & $\begin{array}{l}\text { Phase II single, RCT with single } \\
\text { blinded assessments ( } \mathrm{n}=98) \text {, for } \\
\text { intervention group (simulation- up to } 4 \\
\text { hrs) or control (classroom based- } 1 \mathrm{hr} \text { ). }\end{array}$ & $\begin{array}{l}\text { Objective Structured Clinical } \\
\text { Examination(OSCE) (pre and } \\
\text { post); General Perceived Self- } \\
\text { efficacy scale; Self-reported } \\
\text { competency score. }\end{array}$ & $\begin{array}{l}\text { Intervention group were significantly better } \\
\text { in post-OSCE (of } 24 \text { ) (Pre } M=6.72 \pm 2.2 ; \\
\text { post } M=18.0 \pm 3.2 \text { ) ; no significant } \\
\text { difference in post-intervention General } \\
\text { Perceived Self Efficacy and Self-Reported } \\
\text { Competency scores between control and } \\
\text { intervention groups (Pre } M=130 \pm 13 ; \text { post } \\
M=141 \pm 15 \text { ). The intervention group was } \\
\text { significantly more satisfied with their } \\
\text { teaching method. }\end{array}$ & $\begin{array}{l}\text { Simulation-based education may be an } \\
\text { effective educational strategy to teach nurses } \\
\text { the skills to effectively recognize and manage } \\
\text { a deteriorating patient. }\end{array}$ \\
\hline $\begin{array}{l}\text { Tubaishat and } \\
\text { Tawalbeh, } 2014\end{array}$ & $\begin{array}{l}\text { Randomized } \\
\text { controlled trial of } \\
\text { Nursing students }\end{array}$ & $\begin{array}{l}\text { Cardiac } \\
\text { arrhythmia }\end{array}$ & $\begin{array}{l}\text { A pretest-posttest design to assess } \\
\text {.arrhythmia-related knowledge in } \\
\text { control group (taught by viewing } \\
\text { simulation monitor) and experimental } \\
\text { group }(n=50) \text { who interacted with METI } \\
\text { software to apply treatments to patient } \\
\text { and to live monitor. }\end{array}$ & $\begin{array}{l}\text { 20-item purpose-developed } \\
\text { Knowledge test (MCQ) with } \\
\text { Cronbach alpha of . } 84 \text { in } \\
\text { current study; retention tested } \\
\text { at } 3 \text { months. }\end{array}$ & $\begin{array}{l}\text { Mean knowledge score at post-test was } \\
\text { significantly higher than at pre-test for both } \\
\text { groups. The experimental group } \\
\text { significantly increased knowledge of } \\
\text { cardiac arrhythmia (baseline } 6.2 \pm 2.78) \text { in } \\
\text { the first }(M=13.2 \pm 3.35) \text { and the second } \\
\text { post-test }(12.2 \pm 3.81) \text { compared with those } \\
\text { in the control group }\end{array}$ & $\begin{array}{l}\text { Simulation is a superior teaching strategy that } \\
\text { significantly improved students' arrhythmia } \\
\text { knowledge. }\end{array}$ \\
\hline White et al 2013 & $\begin{array}{l}\text { Randomized } \\
\text { controlled trial with } \\
\text { senior Nursing } \\
\text { students }\end{array}$ & $\begin{array}{l}\text { Distributive } \\
\text { shock/patient } \\
\text { deterioration }\end{array}$ & $\begin{array}{l}\text { RCT: Randomly assigned groups from } \\
\text { a Complex Health Course, }(n=38 \\
\text { controls, } n=16 \text { intervention group) } \\
\text { completed } 2 \text { simulations working in } \\
\text { teams of four, with additional four as } \\
\text { observers).comparison classroom time } \\
\text { was } 2 \text { hrs. }\end{array}$ & $\begin{array}{l}\text { 10-item purposely developed } \\
\text { Distributive Shock } \\
\text { Questionnaire: Cognitive skills } \\
\text { test (DSQ) and Confidence } \\
\text { Level questionnaire (pretest } \\
\text { and post-test). }\end{array}$ & $\begin{array}{l}\text { Neither cognitive skills nor confidence } \\
\text { levels were significantly enhanced by the } \\
\text { use of high-fidelity simulation. Intervention } \\
\text { group scores were knowledge (DSQ): } \\
M=6.13 \pm 1.67 ; M=6.75 \pm 1.61 ; C L \\
M=93.29 \pm 13.80 ; M=111.38 \pm 16.27 \text {. }\end{array}$ & $\begin{array}{l}\text { Neither teaching strategy in isolation is } \\
\text { effective. A combination of teaching } \\
\text { strategies approach is recommended. }\end{array}$ \\
\hline
\end{tabular}


Table 2: Summary of 13 included qualitative studies

\begin{tabular}{|c|c|c|c|c|}
\hline Study & Target group & Simulation topic & Findings & Outcome \\
\hline Bevan 2015 & $\begin{array}{l}\text { First year } \\
\text { Nursing } \\
\text { students }\end{array}$ & Anatomy/physiology & $\begin{array}{l}\text { 11-week course with filmed } \\
\text { feedback highly regarded by } \\
\text { students }\end{array}$ & $\begin{array}{l}\text { Practiced links between } \\
\text { anatomy \& physiology allowed } \\
\text { students to integrate skills }\end{array}$ \\
\hline Diaz et al, 2015. & $\begin{array}{l}\text { Nursing } \\
\text { students }\end{array}$ & $\begin{array}{l}\text { Experience of wearing an } \\
\text { ostomy appliance. }\end{array}$ & $\begin{array}{l}\text { There was insight into student } \\
\text { nurses' caring and empathy. }\end{array}$ & $\begin{array}{l}\text { Findings may influence future } \\
\text { clinical practice. }\end{array}$ \\
\hline $\begin{array}{l}\text { Drake and Ayers } \\
2013\end{array}$ & $\begin{array}{l}\text { Nursing } \\
\text { students }\end{array}$ & $\begin{array}{l}\text { Non-natural end-of-life } \\
\text { simulation }\end{array}$ & $\begin{array}{l}\text { Students valued unexpected } \\
\text { and End-of-Life Simulation }\end{array}$ & $\begin{array}{l}\text { Simulation can address } \\
\text { competencies for fulfilling } \\
\text { nursing, legal responsibilities. }\end{array}$ \\
\hline $\begin{array}{l}\text { Dzioba et al, } \\
2014\end{array}$ & $\begin{array}{l}\text { Senior year } \\
\text { nursing } \\
\text { students }\end{array}$ & $\begin{array}{l}\text { Patient deterioration } \\
\text { scenarios with debriefing }\end{array}$ & $\begin{array}{l}\text { Barriers as well as enablers to } \\
\text { learning themes were identified. }\end{array}$ & $\begin{array}{l}\text { Skills practice in team-based } \\
\text { settings and debriefing was } \\
\text { beneficial. }\end{array}$ \\
\hline $\begin{array}{l}\text { Ewertsson et al, } \\
2015\end{array}$ & $\begin{array}{l}\text { Nursing } \\
\text { students }\end{array}$ & $\begin{array}{l}\text { Experiences of learning in } \\
\text { Clinical Skills laboratories. }\end{array}$ & $\begin{array}{l}\text { Clinical Skills laboratories } \\
\text { formed a bridge linking the } \\
\text { university and clinical practice. }\end{array}$ & $\begin{array}{l}\text { Tension between contexts may } \\
\text { create reflection in students. }\end{array}$ \\
\hline Felton et al 2013 & $\begin{array}{l}\text { Nursing } \\
\text { students }\end{array}$ & Mental health- self-harm & $\begin{array}{l}\text { Helps students to develop skills } \\
\text { across different nursing } \\
\text { domains }\end{array}$ & $\begin{array}{l}\text { A potentially useful approach to } \\
\text { learning. }\end{array}$ \\
\hline $\begin{array}{l}\text { Graham and Atz, } \\
2015\end{array}$ & $\begin{array}{l}\text { Minority nursing } \\
\text { students }\end{array}$ & $\begin{array}{l}\text { Perceptions of high fidelity } \\
\text { simulation }\end{array}$ & $\begin{array}{l}\text { Simulation experiences may act } \\
\text { as a barrier to minority students. }\end{array}$ & $\begin{array}{l}\text { Simulation experiences may } \\
\text { need to be improved. }\end{array}$ \\
\hline $\begin{array}{l}\text { Hober and } \\
\text { Bonnel, } 2014\end{array}$ & $\begin{array}{l}\text { Nursing } \\
\text { students }\end{array}$ & $\begin{array}{l}\text { Perceptions of the } \\
\text { observer role in simulation. }\end{array}$ & $\begin{array}{l}\text { Client simulation can provide } \\
\text { observers with learning } \\
\text { opportunities. }\end{array}$ & $\begin{array}{l}\text { Observer role needs to be re- } \\
\text { framed. }\end{array}$ \\
\hline Lee et al. 2014 & $\begin{array}{l}\text { Junior nursing } \\
\text { students }\end{array}$ & HFS for first time & $\begin{array}{l}\text { Positive and negative } \\
\text { experiences of simulation were } \\
\text { reported.. }\end{array}$ & $\begin{array}{l}\text { Level of task difficulty in } \\
\text { simulation needs to be } \\
\text { considered. }\end{array}$ \\
\hline McClimens 2012 & $\begin{array}{l}\text { Nursing } \\
\text { students }\end{array}$ & $\begin{array}{l}\text { Managing disability } \\
\text { (Epilepsy) }\end{array}$ & $\begin{array}{l}\text { Students benefited from } \\
\text { simulation approach to patient } \\
\text { care. }\end{array}$ & $\begin{array}{l}\text { Lessons learned are applicable } \\
\text { to trainee professionals. }\end{array}$ \\
\hline Najar et al 2014 & $\begin{array}{l}\text { Nursing } \\
\text { students }\end{array}$ & $\begin{array}{l}\text { Experience of high fidelity } \\
\text { simulation }\end{array}$ & $\begin{array}{l}\text { The Simulation Learning Model } \\
\text {-Student Experience was } \\
\text { developed }\end{array}$ & $\begin{array}{l}\text { Students are better equipped to } \\
\text { learn by experiencing } \\
\text { simulation. }\end{array}$ \\
\hline $\begin{array}{l}\text { Reid-Searl et al } \\
2012\end{array}$ & $\begin{array}{l}\text { Nursing } \\
\text { students }\end{array}$ & $\begin{array}{l}\text { Perceptions of high fidelity } \\
\text { silicone simulation }\end{array}$ & $\begin{array}{l}\text { Simulation prepared student for } \\
\text { clinical reality }\end{array}$ & $\begin{array}{l}\text { Simulation may increase } \\
\text { student' sense of clinical } \\
\text { preparedness. }\end{array}$ \\
\hline $\begin{array}{l}\text { Unsworth et al } \\
2012\end{array}$ & $\begin{array}{l}\text { Nursing } \\
\text { students }\end{array}$ & $\begin{array}{l}\text { Physical deterioration in } \\
\text { mental health patients. }\end{array}$ & $\begin{array}{l}\text { Simulation was useful to depict } \\
\text { discrepancies. }\end{array}$ & $\begin{array}{l}\text { Students can identify gaps in } \\
\text { knowledge. }\end{array}$ \\
\hline
\end{tabular}


Table 3 - Characteristics and findings of 16 literature review studies published between 2010 and 2015

\begin{tabular}{|c|c|c|c|c|c|}
\hline Study & Design & Topic & Purpose & Study sample & Findings/Implications \\
\hline Berndt 2013 & $\begin{array}{l}\text { Integrative } \\
\text { review }\end{array}$ & Patient safety & $\begin{array}{l}\text { To synthesize the evidence of simulation } \\
\text { to teach safety in pre-licensure nursing } \\
\text { education. (inclusion period 2003-2011) }\end{array}$ & $\mathrm{N}=17$ articles & $\begin{array}{l}\text { Simulation was as effective as other interactive educational } \\
\text { interventions and more effective than traditional lecture alone; } \\
\text { with higher satisfaction with simulation than for other educational } \\
\text { interventions. Evidence supports use of simulation education to } \\
\text { teach patient safety competencies in pre-licensure nursing } \\
\text { education. [statistical evidence not reported] }\end{array}$ \\
\hline $\begin{array}{l}\text { Blum and } \\
\text { Parcells } 2012\end{array}$ & $\begin{array}{l}\text { Integrative } \\
\text { review }\end{array}$ & Patient safety & $\begin{array}{l}\text { To evaluate quantitative evidence from } \\
\text { research studies re use of simulation in } \\
\text { pre-licensure nursing education directed } \\
\text { at enhancing safety in nursing practice. } \\
\text { (inclusion period 2006-2010) }\end{array}$ & $\begin{array}{l}\mathrm{N}=18 \text { articles, pre- } \\
\text { post intervention and } \\
\text { control- experimental. }\end{array}$ & $\begin{array}{l}\text { Students report simulation as an enjoyable learning activity; } \\
\text { literature does not yet support simulation over other approaches } \\
\text { to teaching of safety competencies in nursing. Nurse educators } \\
\text { must select the most appropriate methods based on the specific } \\
\text { course, student, or program type. }\end{array}$ \\
\hline $\begin{array}{l}\text { Fisher and King } \\
2013\end{array}$ & $\begin{array}{l}\text { Systematic } \\
\text { review }\end{array}$ & $\begin{array}{l}\text { Patient } \\
\text { deterioration }\end{array}$ & $\begin{array}{l}\text { To explore simulation preparation of } \\
\text { nursing students for recognition and } \\
\text { response to the deteriorating patient }\end{array}$ & $\begin{array}{l}\mathrm{N}=18 \text { studies }(2004- \\
2012)\end{array}$ & $\begin{array}{l}\text { Confidence, clinical judgment, knowledge and competence, all } \\
\text { vital in the care of a deteriorating patient, were enhanced. More } \\
\text { research is needed to identify actual outcomes. }\end{array}$ \\
\hline $\begin{array}{l}\text { Foronda et al. } \\
2013\end{array}$ & $\begin{array}{l}\text { Integrative } \\
\text { review }\end{array}$ & $\begin{array}{l}\text { Simulation use } \\
\text { in } \\
\text { undergraduate } \\
\text { nurse } \\
\text { education. }\end{array}$ & $\begin{array}{l}\text { To synthesize research findings } \\
\text { regarding evaluation of simulation in } \\
\text { undergraduate nurse education. } \\
\text { (inclusion period 2008- }\end{array}$ & $\begin{array}{l}\mathrm{N}=101 \text { articles, of all } \\
\text { designs }\end{array}$ & $\begin{array}{l}\text { Emeraina themes were: Confidence/self-efficacv. Satisfaction, } \\
\text { Anxietv/stress. Skills/knowledae. and Interdisciplinarv } \\
\text { experiences. Minimal level of fidelitv needed to produce } \\
\text { sianificant learnina outcomes was inconclusive. More robust } \\
\text { educational research in simulation is warranted. }\end{array}$ \\
\hline $\begin{array}{l}\text { Franklin and Lee } \\
2014\end{array}$ & $\begin{array}{l}\text { Systematic } \\
\text { review and } \\
\text { Meta-analysis }\end{array}$ & Self-efficacy & $\begin{array}{l}\text { To determine the impact of simulation } \\
\text { on self-efficacy in novice nurses } \\
\text { (students or inexperienced nurses) } \\
\text { (inclusion period to 2014) }\end{array}$ & $\begin{array}{l}\mathrm{N}=43 \text { studies; } \\
\text { including experimental } \\
\text { and non-experimental } \\
\text { designs ( } \mathrm{n}=3500 \\
\text { participants) }\end{array}$ & $\begin{array}{l}\text { Simulation improved self-efficacy in both pre-test-post-test } \\
\text { studies (Hedge's } g=1.21,95 \% \mathrm{Cl}[0.63,1.78] ; p<0.001) \text { and in } \\
\text { controlled teaching interventions with experimental designs }(g= \\
0.27,95 \% \mathrm{Cl}[0.1,0.44] ; p=0.002) \text {. In non-experimental designs, } \\
\text { consistent conclusions were limited by significant between-study } \\
\text { differences in effects. Simulation is effective at increasing self- } \\
\text { efficacy among novice nurses, compared with traditional control } \\
\text { groups. }\end{array}$ \\
\hline Gillan et al. 2014 & $\begin{array}{l}\text { Review of } \\
\text { literature }\end{array}$ & End of life care & $\begin{array}{l}\text { End of life care simulation in teaching } \\
\text { nursing students: review of the literature }\end{array}$ & $\begin{array}{l}16 \text { articles (6 } \\
\text { research, } 10 \\
\text { descriptive) (2009- } \\
2013)\end{array}$ & $\begin{array}{l}\text { End of life care simulation is a strong and viable pedagogical } \\
\text { approach to learning for its positive effects on knowledge } \\
\text { acquisition, communication skills, self-confidence, student } \\
\text { satisfaction and level of engagement in learning. Important } \\
\text { factors including psychological safety of students and costs } \\
\text { involved require consideration. Further research is required to } \\
\text { explore issues surrounding end of life care simulation. }\end{array}$ \\
\hline Lapkin,et al 2010 & $\begin{array}{l}\text { Systematic } \\
\text { review of } \\
\text { RCTs }\end{array}$ & $\begin{array}{l}\text { Effectiveness } \\
\text { of HPSMs in } \\
\text { teaching } \\
\text { clinical } \\
\text { reasoning }\end{array}$ & $\begin{array}{l}\text { To review all randomized controlled } \\
\text { trials that assessed effectiveness of } \\
\text { high-fidelity HPSMs in educating } \\
\text { undergraduate nursing students. }\end{array}$ & $\begin{array}{l}N=8 \text { studies (1999- } \\
2009) \text {. }\end{array}$ & $\begin{array}{l}\text { Use of HPSMs improves knowledge acquisition and critical } \\
\text { thinking and enhances students' satisfaction with the learning. } \\
\text { There is a lack of unequivocal evidence of the effectiveness of } \\
\text { using high-fidelity HPSMs in the teaching of clinical reasoning } \\
\text { skills to undergraduate nursing students. }\end{array}$ \\
\hline Larue et al. 2015 & $\begin{array}{l}\text { Systematic } \\
\text { review }\end{array}$ & $\begin{array}{l}\text { Substituting } \\
\text { simulation for } \\
\text { clinical practice }\end{array}$ & $\begin{array}{l}\text { Systematic review to clarify the } \\
\text { contribution of simulation in clinical } \\
\text { nursing education in preparation or }\end{array}$ & $\begin{array}{l}\mathrm{N}=33 \text { high and } \\
\text { medium fidelity }\end{array}$ & $\begin{array}{l}\text { Students and teachers perceived benefits of simulation as an } \\
\text { adjunct to clinical placement in terms of effectiveness, self- } \\
\text { confidence, and preparation for clinical practice. Substituting }\end{array}$ \\
\hline
\end{tabular}




\begin{tabular}{|c|c|c|c|c|c|}
\hline & & & $\begin{array}{l}\text { substitution for clinical placement. } \\
\text { (inclusion period 2008-2014) }\end{array}$ & $\begin{array}{l}\text { studies; study designs } \\
\text { not described. }\end{array}$ & $\begin{array}{l}\text { clinical placement with simulation did not significantly impact on } \\
\text { clinical competency, critical thinking, knowledge acquisition, self- } \\
\text { confidence. Strengths of clinical exposure through both } \\
\text { simulation and clinical placement should be highlighted. } \\
\text { [statistical evidence not reported] }\end{array}$ \\
\hline Lee and Oh 2015 & $\begin{array}{l}\text { Systematic } \\
\text { review and } \\
\text { Meta-analysis }\end{array}$ & $\begin{array}{l}\text { Simulation in } \\
\text { undergraduate } \\
\text { nursing } \\
\text { education } \\
\text { (Korean or } \\
\text { English } \\
\text { language) }\end{array}$ & $\begin{array}{l}\text { To evaluate the effects of high-fidelity } \\
\text { human simulation (HFHS) on cognitive, } \\
\text { affective, and psychomotor outcomes of } \\
\text { learning for nursing students (inclusion } \\
\text { period to 2014). }\end{array}$ & $\begin{array}{l}\mathrm{N}=26 \text { controlled trials } \\
\text { totalling } 2031 \\
\text { participants }\end{array}$ & $\begin{array}{l}\text { Some beneficial effects on cognitive and psychomotor domains } \\
\text { of learning (weighted average effect size in analysis of cognitive } \\
\text { outcomes across studies was }-0.97 \text { for problem-solving } \\
\text { competency, }-0.67 \text { for critical thinking, and }-2.15 \text { for clinical } \\
\text { judgment. Effect size for clinical competence of the psychomotor } \\
\text { domain was }-0.81 \text {. Use of HFHS might positively impact a high } \\
\text { level of cognitive skill and clinical skill acquisition. Research is } \\
\text { required to determine effectiveness to improve knowledge } \\
\text { acquisition and communication skills. }\end{array}$ \\
\hline Oh et al 2015 & $\begin{array}{l}\text { Systematic } \\
\text { review, meta- } \\
\text { analysis }\end{array}$ & $\begin{array}{l}\text { Use of } \\
\text { standardized } \\
\text { patient }\end{array}$ & $\begin{array}{l}\text { To evaluate the effect of simulation- } \\
\text { based learning using standardized } \\
\text { patients (SP) on nursing students }\end{array}$ & $\begin{array}{l}\mathrm{N}=18 \text { controlled trials } \\
\text { (4 randomized, } 14 \\
\text { non-randomized } \\
\text { designs)(-June 2014) }\end{array}$ & 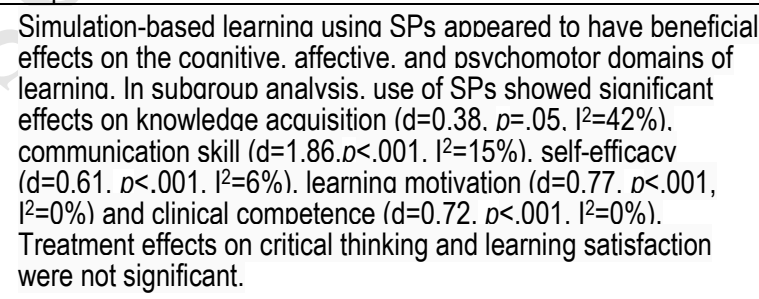 \\
\hline Ricketts 2011 & $\begin{array}{l}\text { Systematic } \\
\text { review }\end{array}$ & $\begin{array}{l}\text { Simulation for } \\
\text { learning }\end{array}$ & $\begin{array}{l}\text { To evaluate potential for future } \\
\text { curricular development using simulated } \\
\text { learning strategies in undergraduate } \\
\text { nursing programmes. }\end{array}$ & $\begin{array}{l}\text { Studies not specified- } \\
\text { approximately } 74 \\
\text { studies. }\end{array}$ & $\begin{array}{l}\text { Simulated learning in a clinical skills laboratory is reported to } \\
\text { increase student confidence and prepares students for real } \\
\text { clinical setting, however, students learn at different rates. Further } \\
\text { evaluation of current learning methods within simulation may } \\
\text { offer appraisal of the preparation of students for clinical practice. }\end{array}$ \\
\hline Ross 2012 & $\begin{array}{l}\text { Compre- } \\
\text { hensive review }\end{array}$ & $\begin{array}{l}\text { Psychomotor } \\
\text { skills } \\
\text { acquisition }\end{array}$ & $\begin{array}{l}\text { To discuss state of the science on the } \\
\text { use of simulation for psychomotor skill } \\
\text { acquisition. }\end{array}$ & $\begin{array}{l}\mathrm{N}=19 \text { studies } \\
\text { included }\end{array}$ & $\begin{array}{l}\text { Limited empirical evidence exists to support the efficacy of } \\
\text { simulation to teach psychomotor skills, with a need for more high } \\
\text { quality research in nursing. }\end{array}$ \\
\hline $\begin{array}{l}\text { Skrable \& } \\
\text { Fitzsimons } 2014\end{array}$ & $\begin{array}{l}\text { Systematic } \\
\text { review }\end{array}$ & $\begin{array}{l}\text { Evaluating } \\
\text { simulation } \\
\text { impact }\end{array}$ & $\begin{array}{l}\text { To synthesize research findings } \\
\text { evaluating simulation in associate } \\
\text { degree nursing education. }\end{array}$ & $\begin{array}{l}\mathrm{N}=21 \text { studies: } 13 \\
\text { quantitative, } 3 \text { quasi- } \\
\text { experimental, } 3 \\
\text { qualitative, } 2 \text { mixed } \\
\text { methods studies. } \\
\text { (2010-2013) }\end{array}$ & $\begin{array}{l}\text { Exposure to HFPS increases standardized critical thinking test } \\
\text { scores, but not more than other teaching modalities. The impact } \\
\text { of simulation on students' ability to use critical thinking is not } \\
\text { known. HFPS can increase knowledge acquisition, skill } \\
\text { performance and confidence levels. High satisfaction with } \\
\text { simulation and integration into clinical education were reported. }\end{array}$ \\
\hline Shearer 2013 & $\begin{array}{l}\text { Integrative } \\
\text { review }\end{array}$ & $\begin{array}{l}\text { Safety } \\
\text { behaviours }\end{array}$ & $\begin{array}{l}\text { To collected and analvze evidence of } \\
\text { patient safetv outcomes of simulation } \\
\text { education published } 2007-2012\end{array}$ & $\begin{array}{l}\mathrm{N}=18 \text { articles, quasi- } \\
\text { experimental, and } \\
\text { experimental studies }\end{array}$ & $\begin{array}{l}\text { Simulation-enhanced clinical experiences mav decrease } \\
\text { medication errors. Evidence about perceived improvement in } \\
\text { safer communication has not been translated into practice. } \\
\text { Knowledqe and attitudes of safety mav be improved with } \\
\text { simulation, depending on the students' educational levels. }\end{array}$ \\
\hline Stroup 2014 & $\begin{array}{l}\text { Integrative } \\
\text { review }\end{array}$ & $\begin{array}{l}\text { Simulation } \\
\text { usage in } \\
\text { fundamentals } \\
\text { of nursing }\end{array}$ & $\begin{array}{l}\text { To review evidence related to simulation } \\
\text { application in foundational nursing } \\
\text { education }\end{array}$ & $\begin{array}{l}N=15 \text { studies }(2003- \\
2014)\end{array}$ & $\begin{array}{l}\text { Simulation promotes cognitive and psychomotor results } \\
\text { equivalent to traditional methods with higher levels of faculty } \\
\text { satisfaction and critical thinking development. }\end{array}$ \\
\hline
\end{tabular}




\begin{tabular}{|l|l|l|l|l|l|}
\hline $\begin{array}{l}\text { Vincent et al. } \\
2015\end{array}$ & $\begin{array}{l}\text { Systematic } \\
\text { review and } \\
\text { Meta-analysis }\end{array}$ & $\begin{array}{l}\text { Psychomotor } \\
\text { clinical } \\
\text { performance }\end{array}$ & $\begin{array}{l}\text { To determine impact of high-fidelity } \\
\text { simulation on improving the } \\
\text { psychomotor clinical performance of } \\
\text { undergraduate nursing students. }\end{array}$ & $\begin{array}{l}\text { N=8 articles; } \\
\text { quantitative studies, } \\
\text { various designs } \\
\text { including RCT, pre- } \\
\text { test/post-test } \\
\text { experiments or quasi- } \\
\text { experiments. }(n=571 \\
\text { participants) }\end{array}$ & $\begin{array}{l}\text { A meta-analysis conducted for the effect size and direction of } \\
\text { impact yielded a range of }-0.26 \text { to +3.39. A positive effect was } \\
\text { shown in seven of eight studies. However, varied research } \\
\text { designs and six unique appraisal instruments were used. High- } \\
\text { and medium-fidelity simulation can build global skills sets to } \\
\text { accelerate the novice-to expert process. }\end{array}$ \\
\hline
\end{tabular}

${ }^{*} \mathrm{HFS}=$ high fidelity simulation

experiments. ( $n=571$ 
Table 4 Overall weighted difference in Knowledge

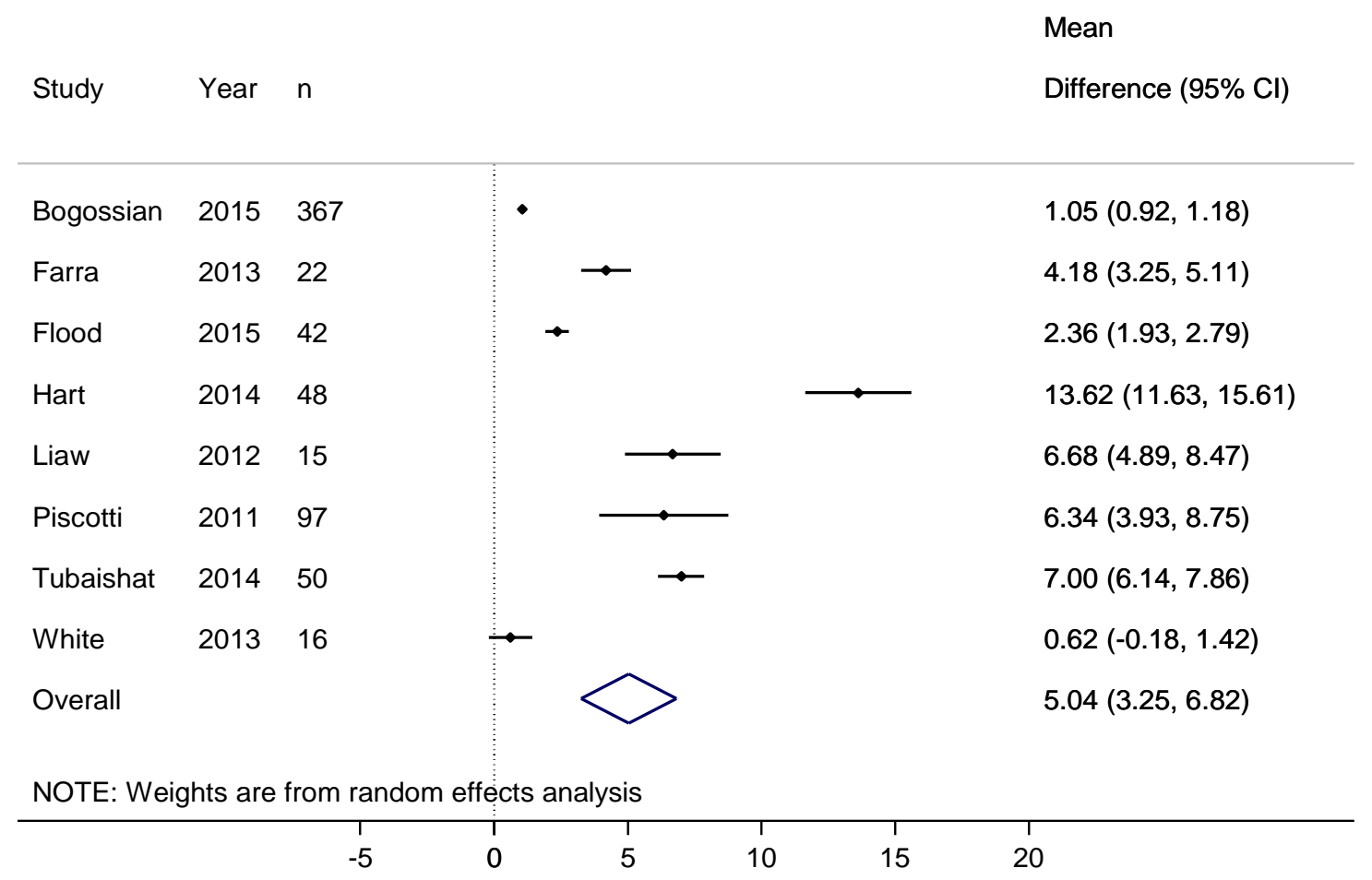


Figure 1 Flow diagram of study selection process

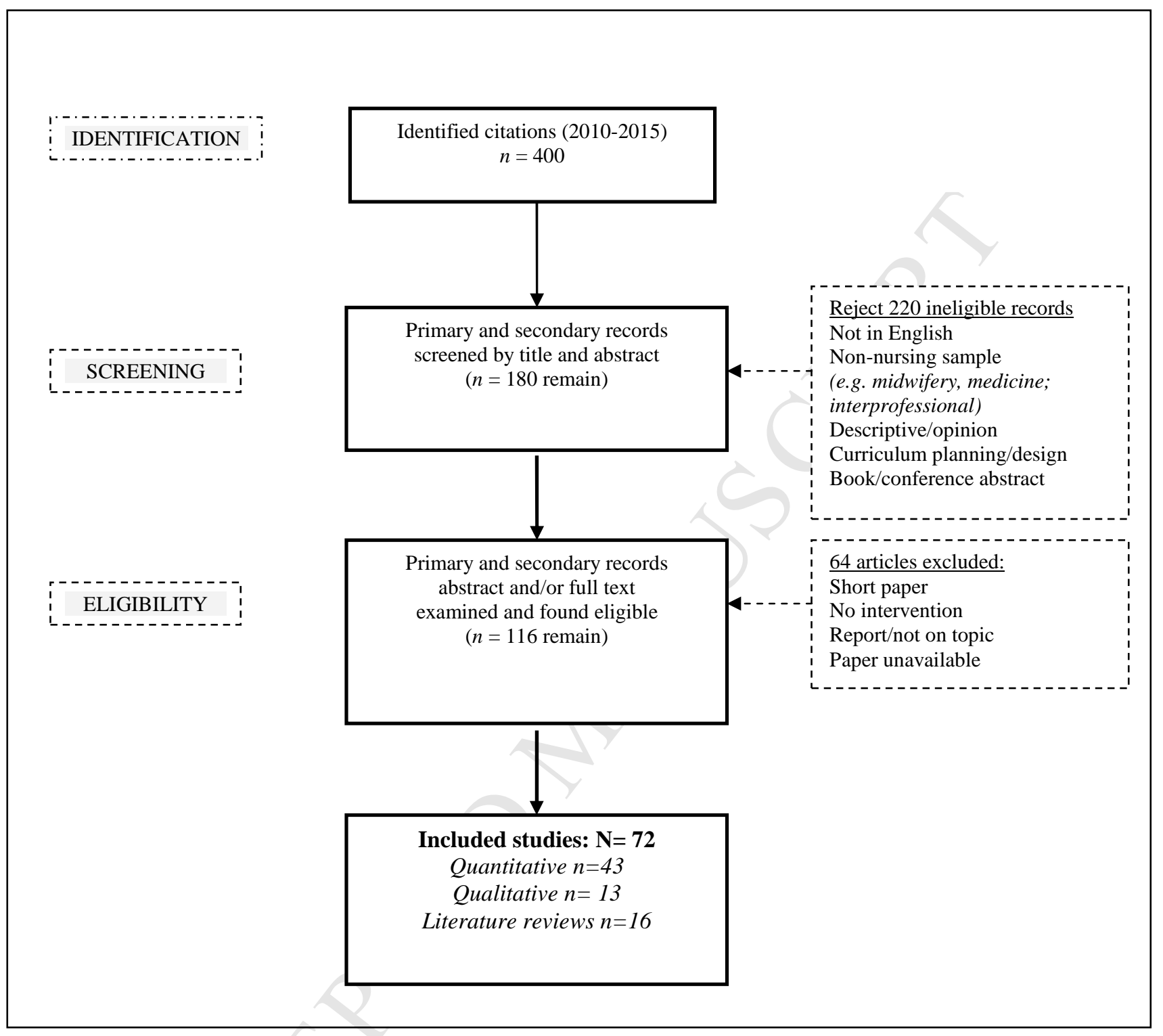


Conflict of interest statement

The authors declare they have no conflict of interest.

Funding statement

No funding was provided for this study 
Box 1 'Realistic' medium and high fidelity simulation environments 
Medium to high fidelity full-scale simulation incorporates a computerized full-body manikin that can be programmed to provide physiologic responses. With use of actual medical equipment and supplies, this forms a realistic healthcare environment for face-to-face simulation.

A standardized patient (a student or paid actor) can be taught to portray a patient in a realistic and consistent manner -also signifying high fidelity (believability).

e-Simulation involves goal-based digital simulations that takes place via a computer screen. Use of multimedia (video, text, voice, and feedback) provide an interactive Web-based educational experience.

Virtual reality simulation combines a computer-generated environment (eg., digital patient or nurse) with tactile, auditory and visual stimuli for learning.

Source: Cant and Cooper 2010, 2015. 